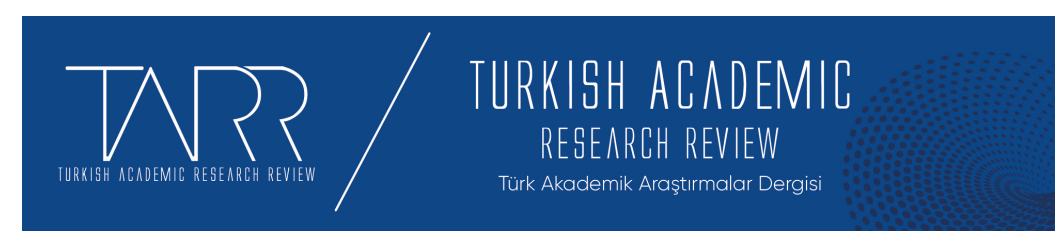

e-ISSN: 2602-2923 Yıl/Year: 2021 Cilt/Volume: 6 Sayı/Issue: 2

\title{
Türkiye'de Turistik Konaklama Türlerine ve Dağılışına Coğrafi Bir Bakış
}

A Geographic view on the Touristic Accommodation Type and Distribution in Turkey

\section{Mehmet Akif CEYLAN - Mehmet Emin YAKUT}

Prof. Dr., Marmara Üniversitesi Fen Edebiyat Fakültesi Coğrafya Bölümü, İstanbul, maceylan@marmara.edu.tr, Orcid ID: 0000-0002-1195-7436

Dr. Öğr. Üyesi, Bingöl Üniversitesi Fen Edebiyat Fakültesi Coğrafya Bölümü, Bingöl, meyakut@bingol.edu.tr, Orcid ID: 0000-0002-2745-7110

\begin{tabular}{r|l} 
Makale Bilgisi & Article Information \\
Makale Türü - Article Type & Araştırma Makalesi / Research Article \\
Geliş Tarihi - Date Received & 2 Mayıs / May 2021 \\
Kabul Tarihi - Date Accepted & 23 Haziran / June 2021 \\
Yayın Tarihi - Date Published & 25 Haziran / June 2021 \\
Yayın Sezonu & Nisan - Mayıs- Haziran \\
Pub Date Season & April - May - June
\end{tabular}

Atıf / Cite as: Ceylan, M. A.-Yakut, M. E. (2021). Türkiye'de Turistik Konaklama Türlerine ve Dağılışına Coğrafi Bir Bakış/A Geographic view on the Touristic Accommodation Type and Distribution in Turkey. Turkish Academic Research $\begin{array}{lllll}\text { Review, } & 6 & \text { (2), } & 697-724 . & \text { Retrieved }\end{array}$ https://dergipark.org.tr/tr/pub/tarr/issue/62824/931416

Intihal / Plagiarism: Bu makale, en az iki hakem tarafından incelenmiş ve intihal içermediği teyit edilmiştir. / This article has been reviewed by at least two referees and confirmed to include no plagiarism. https://dergipark.org.tr/tr/pub/tarr

Copyright (C) Published by Mehmet ŞAHIN Since 2016- Akdeniz University, Faculty of Theology, Antalya, 07058 Turkey. All rights reserved.

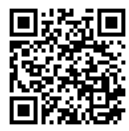

Turkish Academic Research Review - Türk Akademik Araştırmalar Dergisi 


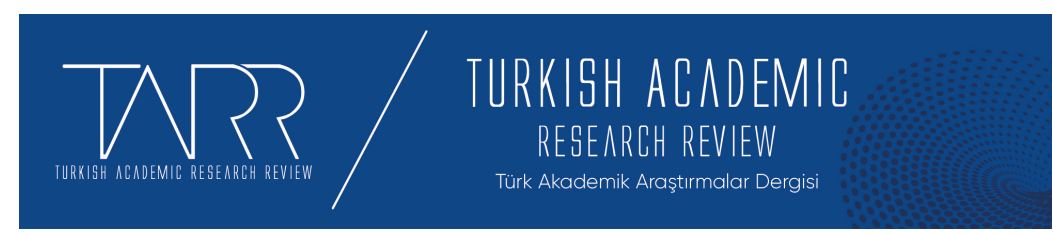

e-ISSN: 2602-2923 Yll/Year: 2021 Cilt/Volume: 6 Sayı/Issue: 2

\title{
Türkiye'de Turistik Konaklama Türlerine ve Dağılışına Coğrafi Bir Bakış
}

\author{
Mehmet Akif CEYLAN - Mehmet Emin YAKUT
}

Öz

$\mathrm{Bu}$ çalışmada, turizmin gelişmesinde büyük öneme sahip olan konaklama tesislerinin türleri ve dağılışı ele alınmıştır. Turizm sektörünün sabit elemanı olarak değerlendirilen konaklama tesislerinin mekâna dağılışı incelenerek, konaklama tesisleri ile turistik yöreler ve iller arasındaki ilişkiler üzerinde durulmuştur. Değerlendirmeler yapılırken istatistik veriler ve literatür bilgilerinin yanı sıra coğrafi arazi çalışmaları esnasında yapılan gözlemlerden de büyük ölçüde yararlanılmıştır.

Herhangi bir mekânın fiziki, beşeri ve kültürel potansiyeli, turistik faaliyetleri ve konaklama türlerini büyük ölçüde belirlemektedir. Başlıca turistik konaklama türleri arasında otel, motel, tatil köyü, pansiyon, karavan, bungalov, çadır-kamping ve oberj yer almaktadır. Turistik konaklama tesisleri genellikle Türkiye'nin batı, güneybatı ve güney kıyı bölgelerinde yoğunlaşmıştır. Bu durum, kıyı kesimlerinin doğal ve beşeri turistik potansiyelleriyle yakından ilgilidir. Ayrıca teşvik edici politikalar nedeniyle Türkiye'de turistik konaklama tesislerinin sayısında 1980, özellikle 2000 y1lından sonra belirgin artışlar söz konusu olmuştur. Nitekim günümüz itibariyle Türkiye'nin turizm işletme ve belediye işletme belgeli toplam yatak kapasitesi 1,5 milyonun üzerine çıkmıştır.

Turizm işletme belgeli konaklama tesislerinin illere dağılışında, Antalya 807 tesisle açık ara ilk sırada gelmektedir. Daha sonra sırasıyla İstanbul 644, Muğla 412, İzmir 222, Ankara 182, Nevşehir 110, Balıkesir 95 ve Aydın 92 tesisle takip etmektedir. Bakanlık işletme belgeli en az tesis ise Kilis'te olup yalnızca 1 tesis mevcuttur. Diğer illerden Bayburt ve Siirt'te 2'şer, Bingöl ve Iğdır'da 3'er tesis hizmet vermektedir. Son yillarda alternatif turizm türleriyle birlikte turizm hareketlerinin ve konaklama tesislerinin ülke sathına yayılma eğiliminde olduğu ayırt edilmektedir. Yoğun bir istihdam sağlayan turistik konaklama tesislerinin ve alternatif turizm türlerinin Türkiye'nin iç bölgelerinde bulunan illerinde de teşvik edilerek yaygınlık kazanmasına önem verilmelidir. Böylece iller arasında gelişmişlik farkının azaltılmasında turizm sektöründen daha fazla yararlanılmalıdır.

Anahtar Kelimeler: Turizm, Konaklama, Konaklama Türleri, Otel, Türkiye.

\section{A Geographic view on the Touristic Accommodation Type and Distribution in Turkey}

\begin{abstract}
In this study, the types and distribution of accommodation facilities, which are of great importance in the development of tourism, are discussed. By examining the distribution of accommodation facilities, which are considered to be the permanent elements of the tourism sector, the relations between accommodation facilities and touristic regions and provinces have been emphasized. While making evaluations,
\end{abstract}


statistical data and literature information as well as observations made during geographic research trips were used.

The physical, human and cultural potential of any venue determines the touristic activities and accommodation types to a great extent. Major tourist accommodation types include hotels, motels, holiday villages, hostels, caravans, bungalows, tentcamping and oberj. Tourist accommodation facilities are generally concentrated in the southern and southwestern coastal regions of our country. This situation is closely related to the natural and human tourism potential of the coastal areas. In addition, there has been a significant increase in the number of touristic accommodation facilities in our country after 1980, especially after 2000 , due to encouraging policies. Indeed, Turkey's tourism businesses and municipalities certified today total bed capacity has increased to over 1,5 million.

Antalya is by far the first with 807 facilities in the distribution of accommodation facilities with tourism operation certificates to the provinces. It is followed by İstanbul 644, Muğla 412, İzmir 222, Ankara 182, Nevșehir 110, Balıkesir 95 and Aydın 92 facilities, respectively. The least facility with the Ministry's operation certificate is in Kilis and there is only 1 facility. From other provinces, 2 facilities each in Bayburt and Siirt, and 3 facilities each in Bingöl and Iğdır. In recent years, it is distinguished that tourism movements and accommodation facilities with alternative tourism types tend to spread throughout the country. It should be given importance that touristic accommodation facilities and alternative tourism types, which provide intense employment, are encouraged and become widespread in provinces located in the inner regions of Turkey. Thus, the tourism sector should be utilized more in reducing the development gap between provinces.

Keywords: Tourism, Accommodation, Accommodation Types, Hotel, Turkey.

\section{Structured Abstract}

In order for tourism to develop in any place or country in the world, three basic elements must be found. These are attraction, transportation and accommodation and are formulated as the three A of tourism (attraction, accessibility, accommodation). Undoubtedly, it is necessary to add organization to these. Because the organization has an important function in activating the existing tourism potential.

Today, getting away from the busy and stressful city environment or monotonous daily life and spending time in a different place has become an important need. This need is met in touristic accommodation facilities that mostly serve within the scope of tourism activities. Tourists, especially overnight stays in these facilities, rest, entertainment, eating and drinking, shopping, sports, etc. meets many needs.

Since tourist accommodation facilities are commercial businesses, they tend to keep their product range wide in order to satisfy customers with different demands and expectations. Thus, the type and size of accommodation facilities are shaped according to the service capacity. Accommodation facilities are mostly classified according to comfort level and bed capacity.

In this study, the types and distribution of accommodation facilities, which are of great importance in the development of tourism, are discussed. The distribution of accommodation facilities, which are considered as permanent elements of the tourism sector, was examined, and the relations between accommodation facilities and touristic regions and provinces were emphasized. 
Hotels, motels and hostels are recognized as traditional accommodation facilities. Apart from these, holiday villages, camping, hostel, oberj, holiday site, holiday villa, farmhouse / village house, golf facility, rural tourism facility, private facility, tourism complex and highland house are classified as other accommodation facilities. Hotels have a special place in tourist accommodation. They are the most used touristic accommodation facilities in terms of both being widespread and serving in various concepts and types. Among the hotel types, 5 -star hotels also have a different position. For a hotel to be 5-star, it must meet many criteria. For this reason, there are no 5 -star hotels in every city.

Tourist accommodation facilities are generally concentrated in the western, southwestern and southern coastal regions of our country. This situation is closely related to the natural and human tourism potential of the coastal areas. In addition, there has been a significant increase in the number of touristic accommodation facilities in our country after 1980 , especially after 2000 , due to encouraging policies. So much so that by 1990 , the number of touristic accommodation increased 7 times compared to 1980 with 3102 . As a matter of fact, as of today, the total bed capacity of Turkey with tourism management and municipal management certificates has exceeded 1.5 million. The Tourism Incentive Law enacted in 1981 had a great effect on the increase in the number of facilities. Since this incentive especially supports coastal tourism, the development of touristic accommodation in provinces with coasts to the Aegean and the Mediterranean has accelerated.

While the number of foreign tourists visiting our country was around 1 million in 1980, this number exceeded 5 million in 1990 and 10 million in 2000. While 28,632,204 people visited our country in 2010, 36,244,632 in 2015 and 15,971,201 in 2020. Tourism activities were adversely affected due to the Covid-19 epidemic that affected the world in 2020. However, in 2019, over 45 million foreign tourists visited our country. This last figure is more than $50 \%$ of the country's population. With more than 2 million foreign tourists visiting our country in 2020, Russians take the first place.

Touristic accommodation facilities in Turkey are classified according to the ministry and municipality operating certificate and their types. Adherence to the type criteria is mandatory in touristic accommodation facilities. According to the information received from the Ministry of Culture and Tourism, all accommodation facilities are expected to have a ministry management certificate in the coming period. Therefore, a new regulation is required for the classification of accommodation facilities according to their types. It would be beneficial to reduce the types of accommodation used in the classification of touristic accommodation facilities. In its current form, there is a confusion in both authorization and classification.

When examining the distribution of accommodation facilities with tourism management certificates to provinces, Antalya comes first with 807 facilities by far. It is followed by İstanbul 644, Muğla 412, İzmir 222, Ankara 182, Nevşehir 110, Balıkesir 95 and Aydın 92 facilities, respectively. The least facility with Ministry operating certificate is in Kilis and there is only one facility. There are 2 facilities in Bayburt and Siirt and 3 facilities in Bingöl and Iğdır from other provinces. Today, 4218 facilities with tourism management certificates, 487,376 rooms and 1,020,985 beds have been reached.

The most common type of accommodation in Turkey is hotel. Hotels in Turkey are classified up to 5 stars. Tourist hotels are concentrated in the provinces of Antalya, Muğla, Aydın, İzmir, İstanbul, Mersin and Balıkesir. Afyonkarahisar and Bursa rank first in the number of 5-star thermal hotels. Nevşehir comes first in the hostel type, and then İzmir and the surrounding provinces follow. Holiday villages are

Turkish Academic Research Review - Türk Akademik Araştırmalar Dergisi 
concentrated in Antalya. Accommodation types such as mountain lodges, farmhouses, motels and camping are mostly distributed in the inner regions.

In the distribution order of accommodation facilities in Turkey, the tendency of more concentration is distinguished especially in the provinces located on the west, southwest and south Anatolian coasts. In this context, the provinces of Antalya, Muğla, İzmir and Aydın are at the top. The fact that the natural and human environment conditions are really convenient leads to the prominence of tourism activities in these places. On the other hand, the fact that Nevşehir, located in Central Anatolia, is ahead in the ranking, undoubtedly has a significant effect on the natural and cultural attractiveness of the fairy chimneys, which are one of the most original landforms in the Ürgüp-Göreme region. Therefore, very close relationships are observed between the importance and distribution of natural and human touristic attractions and the number, type and distribution of accommodation facilities. This situation reveals the importance of regional character in integrated tourism planning studies. In addition, attention should be paid to the widespread use of touristic accommodation facilities, which provide intensive employment, by promoting alternative tourism types in provinces located in the inner regions of Turkey. Thus, the tourism sector should be used more in reducing the development gap between provinces.

\section{Giriş}

Yeryüzünde herhangi bir yerde veya ülkede turizmin gelişebilmesi için üç temel unsurun bulunması gerekmektedir. Bunlar çekicilik, ulaşım ve konaklama olup turizmin üç A'sı (attraction, accessibility, accommodation) olarak formüle edilir. Şüphesiz bunlara organizasyonu da ilave etmek lazımdır. Çünkü mevcut turizm potansiyelinin harekete geçirilmesinde organizasyon önemli bir işleve sahiptir.

Konaklama, seyahat esnasında bir yerde kalmak ve geceyi geçirmek anlamına gelir. Turizm faaliyetlerinde ise, beslenme ve gecelemeyi birlikte ifade etmektedir (Özgüç, 2007: 102). Konaklama eyleminin gerçekleștiği mekânlar konaklama tesisi olarak adlandırılır. Konaklama tesisleri bir ihtiyaçtan doğmuştur. İnsanlar sürekli ikamet ettikleri yerlerde kalıcı konutlarda bu ihtiyacını karşılamaktadır. Ancak geçici süre ile gittikleri yerlerde geceyi geçirebilecekleri ve ihtiyaçlarını giderebilecekleri konutlara ihtiyaç duyarlar. Bunlar da konaklama tesisi olarak tanımlanmaktadır.

Konaklama tesislerinin temel işlevi geceleme ihtiyacını karşılamaktır. Bununla birlikte dinlenme, eğlenme, yeme-içme, spor, alışveriş gibi çeşitli ihtiyaçlar da giderilmektedir. Günümüzde rekabet şartlarının gelişmesiyle birlikte tesislerde müşteri memnuniyeti ön plana çıktığından daha farklı hizmetler de sunulmaktadır (Koçhan, 2015: 13).

Konaklama tesisleri aynı zamanda birer ticari tesis, ticari işletmedir. Turistlerin gelir düzeyi, seyahat nedeni ve beklentileri birbirinden farklıdır. Dolayısıyla farklı ihtiyaçlara sahip müşterilerine hitap edebilecek ürün yelpazesini mümkün olduğunca geniş tutmaya çalışmaktadırlar. Tesislerin büyüklüğü de bu kapasiteye göre şekil almaktadir (Azaltun ve Kaya, 2010: 2).

Turizmin ve bunun temel bir parçası olan konaklama tesislerinin en önemli etkisi ekonomik büyümede görülmektedir. Türkiye'de özellikle 1980'den günümüze doğru turizmin ekonomi içindeki payı sürekli artmıştır. Döviz girdisi nedeniyle Türkiye'nin dış ticaret açığının kapatılmasına katkıda bulunarak milli gelir üzerinde olumlu etki oluşturmaktadır. Turizm aynı zamanda Türkiye için önemli bir istihdam ve tanıtım alanıdır (Dilber, 2007: 206). 2019 yılına ait verilere göre, konaklama ve 
yiyecek hizmetlerinin gayrisafi yurtiçi hâsıla (GSYH) içindeki payı \%3,4'ten \%3,1'e gerilemiştir. Pandemi koşulları nedeniyle bu oranın 2020'de biraz daha düşeceği tahmin edilmektedir. Turizm gelirlerinin ihracat içindeki payı 2019 y1lı itibariyle \%20,1'e karşılık gelmektedir (www.tursab.org.tr/istatistikler).

Türkiye'yi ziyaret eden yabancı turist sayısı 1980'de 1 milyon civarında iken, bu rakam 1990'da 5 milyonu ve 2000'de 10 milyonu aşmıştır. Yine 2010 yılında 28.632.204 kişi Türkiye'yi ziyaret ederken, 2015'te 36.244.632, 2020'de ise 15.971.201 kişi ziyaret etmiştir. 2020 yılında dünya genelinde etkisini gösteren Covid-19 salgını nedeniyle turizm faaliyetleri olumsuz etkilenmiştir. Hâlbuki 2019 yılında 45 milyonun üzerinde olan yabancı turist kitlesi Türkiye'yi ziyaret etmişti. Bu son rakam ülke nüfusunun \%50'sinden fazladır. İç turizm hareketliliği ile birlikte düşünüldüğ̈ünde turist sayısı daha da artmaktadır.

Türkiye'yi 2020 yılında ziyaret eden yabancı turistler içinde 2 milyondan fazla bir rakamla Ruslar ilk sırada yer almaktadır. Aynı yıl Bulgaristan ve Almanya'dan 1 milyonda fazla turist giriş yapmıştır. 2019 yilında ise, \%16 ile Rusya ilk sırada yer almaktadir. Daha sonra sirasiyla Almanya (\%11), İngiltere (\%6), Bulgaristan (\%5), İran (\%4), Gürcistan (\%4), Ukrayna (\%3), Irak (\%2), Hollanda (\%2) ve Fransa (\%2) gelmektedir (Tablo 1). Yabancı turistlerin geldikleri kıtalara dağılımında, \%45 ile Avrupa ilk sırada yer almaktadır. Daha sonra \%29 ile Bağımsız Devletler Topluluğu ve \%19 ile Asya gelmektedir. Turistler sirasıyla İstanbul (\%39), Antalya (\%25), Edirne (\%14), Muğla (\%5) ve Artvin (\%3) sınır kapılarından giriş yapmışlardır.

Tablo 1: Türkiye’yi Ziyaret Eden Turistlerin Geldikleri Ülkeler (2019-2020)

\begin{tabular}{|l|c|c|l|c|c|}
\hline \multicolumn{3}{|c|}{2019 Yılı } & \multicolumn{3}{c|}{ 2020 Yılı } \\
\hline Ülke & Turist Sayısı & Oranı \%) & Ülke & Turist Sayısı & Oranı \%) \\
\hline Rusya Fed. & 6.694 .453 & 16,4 & Rusya Fed. & 2.128 .758 & 13,3 \\
\hline Almanya & 4.649 .494 & 11,4 & Bulgaristan & 1.242 .962 & 7,7 \\
\hline İngiltere & 2.442 .375 & 6,0 & Almanya & 1.118 .932 & 7,0 \\
\hline Bulgaristan & 2.254 .444 & 5,5 & Ukrayna & 997.652 & 6,2 \\
\hline İran & 1.825 .386 & 4,4 & İngiltere & 820.709 & 5,1 \\
\hline
\end{tabular}

Kaynak: Kültür ve Turizm Bakanlığı, 2020.

Türkiye'de turizm hareketliliğinde batı, güneybatı ve güney kıyılarında yer alan Antalya, Muğla ve Aydın illeri ön plana çıkmaktadır (Akıncı, 2010: 6). Bunların yanında İstanbul, İzmir, Bursa, Konya, Denizli, Ürgüp-Göreme yöresi gibi turizm konusunda önemli destinasyonlar bulunmaktadır. Özellikle alternatif turizm türleri ile birlikte son yıllarda turizm hareketlerinin ülke sathına yayılmaya başladığı ayırt edilmektedir.

Turistik konaklama türlerinden otel, motel ve pansiyon geleneksel konaklama türleri içinde değerlendirilir. Günümüzde turistik konaklama tesisleri daha çok konfor ve yatak kapasitelerine göre sınıflandırılır (Özgüç, 2007: 102). Türkiye'de ise turistik konaklama tesisleri, bakanlık ve belediye işletme belgesine ve türlerine göre sınıflandırılır. Turistik konaklama tesislerinde tür kriterlerine bağlılık mecburidir. Kültür ve Turizm Bakanlığı'ndan alınan bilgilere göre, önümüzdeki dönemde tüm konaklama tesislerinin bakanlık işletme belgesine sahip olması beklenmektedir. $\mathrm{Bu}$ nedenle, konaklama tesislerinin türlerine göre sinıflandırılmasında yeni bir düzenleme gerekmektedir. Turistik konaklama tesislerinin sınıflandırılmasında kullanılan konaklama türlerinin azaltılması faydalı olacaktır. Mevcut haliyle hem yetki hem de sınıflandırma konusunda bir karmaşa söz konusudur.

Türkiye'de turistik konaklama tesislerinin gelişimi 1980'den sonra hızlanmıştır. Öyle ki 1990'a gelindiğinde turistik konaklama sayısı 3102 ile 1980'e göre 7 kat

Turkish Academic Research Review - Türk Akademik Araştırmalar Dergisi 
artmıştır. Tesis sayısının artmasında, 1981'de çıkarılan Turizm Teşvik Kanunu'nun büyük etkisi olmuştur. Bu teşvik özellikle kıyı turizmini desteklediği için Ege ve Akdeniz'e kıyısı olan illerde turistik konaklamanın gelişimi oldukça hızlanmıştır. Dolayısıyla konaklama tesisleri de o yörelerde yoğunlaşmaktadır (Alaeddinoğlu vd, 2006: 148). Günümüzde turizm işletmeli 4.218 tesis, 487.376 oda ve 1.020 .985 yatak kapasitesine ulaşılmıştır (Kültür ve Turizm Bakanlığı, 2020). Ayrıca turistik konaklama tesisleri daha geniş bir coğrafyaya yayılış eğilimine de girmiştir.

\section{Amaç ve Yöntem}

Bu makalede turizmin en önemli öğelerinden biri olan konaklama tesislerinin türleri ve Türkiye'de dağılışının araştııılması amaçlanmıştır. Turizm sektörü ve konaklama tesislerinin ülke ekonomisi içindeki yerine vurgu yapılmış, gelişimi ve dağılışı ortaya konulmaya çalışılmıştır. Bunun için ilk önce literatür çalışması yapılmıştır. Daha sonra TÜIK, Kültür ve Turizm Bakanlığı ve TÜRSAB'tan elde edilen veriler nicel yöntemlerle değerlendirilmiştir. Bu çalışmaya 2020'de başlanılmış ve 2021'in başında tamamlanmıştır. Temin edilen verilerin bir kısmı Arcgis 10.5 programı yardımıyla haritalandırılmıştır. Harita, tablo, grafik ve fotoğraflarla desteklenen çalışma yorum ve analizlerle şekillendirilmiştir. Sayfa sınırlaması olması nedeniyle makalede fotoğraf ve grafik gibi görsel malzemeler az sayıda verilebilmiştir.

\section{Türkiye'de Turistik Konaklama Türleri Ve Dağılışı}

Konaklama tesislerinin sınıflandırılması ülkeden ülkeye değişebilmektedir. Bununla birlikte sınıflandırmada genellikle, fiziki kapasite, hizmet amacı, büyüklüğü, statüsü, konfor derecesi ve ulaşım imkânları gibi ölçütler kullanılmışır (Akıncı, 2010: 19). Türkiye'de turistik konaklama tesisleri Turizm Bakanlığı işletme belgeli ve belediye işletme belgeli olmak üzere iki ana grupta toplanmaktadır. 01.06.2019 tarih 30791 sayılı Resmi Gazete'de yayımlanan Turizm Tesislerinin Niteliklerine Illişkin Yönetmelik'te Turizm Bakanlığ 1 işletme belgeli konaklama türleri ve özellikleri detaylı bir şekilde belirlenmektedir (Tablo 2). Turizm coğrafyasında ise geleneksel ve tamamlayıcı konaklama tesisleri şeklinde iki ana grupta ele alınmaktadır.

Bakanlık belgeli turistik konaklama tesislerinden faaliyette olanlar turizm işletme belgeli konaklama tesisleri olarak tanımlanır. Yapımı devam eden ve henüz faaliyete geçmemiş konaklama tesisleri de turizm yatırım belgeli konaklama tesisleri olarak adlandırılır. Tablo 2 ve Grafik 1 incelendiğinde, konaklama türleri arasında \%74 oranıla farklı yıldızlı oteller ilk sırada yer almaktadır. Daha sonra \%10 oranıyla özel tesis, \%6 ile müstakil apart otel, $\% 3$ ile pansiyon ve $\% 2$ 'şer oran ile butik otel, termal otel ve tatil köyü sıralanmaktadır. Oteller kendi içinde 1 yıldızlı (52), 2 yıldızlı (381), 3 yıldızlı (1.110), 4 yıldızlı (869) ve 5 yıldızlı (704) otel olarak sinıflandırılırken, termal oteller 3 yıldızlı (18), 4 yıldızlı (31) ve 5 yıldızlı (41) termal otel, tatil köyleri birinci sınıf (69) ve ikinci sınıf (9) olarak sınıflanmaktadır. 
Tablo 2. Türlerine Göre Bakanlık Belgeli Turistik Konaklama Tesisleri

\begin{tabular}{|c|c|c|c|c|c|}
\hline \multicolumn{4}{|c|}{ Turizm İşletme Belgeli } & \multicolumn{2}{|c|}{ Turizm Yatırım Belgeli } \\
\hline Türü & Sinıfi & Tesis Sayısı & Yatak Sayısı & Tesis Sayısı & Yatak Sayısı \\
\hline \multirow{5}{*}{ Otel } & 1 Yildizli & 52 & 2.793 & 27 & 1.275 \\
\hline & 2 Yildızlı & 381 & 26.215 & 9 & 686 \\
\hline & 3 Yildızlı & 1.110 & 122.099 & 203 & 21.373 \\
\hline & 4 Yildızlı & 869 & 236.199 & 155 & 39.252 \\
\hline & 5 Yildıli & 704 & 474.857 & 129 & 75.469 \\
\hline \multirow{3}{*}{ Termal Otel } & 3 Yildizli & 18 & 2.160 & 4 & 815 \\
\hline & 4 Yildizli $_{1}$ & 31 & 7.664 & 5 & 1.417 \\
\hline & 5 Yildızlı & 41 & 21.411 & 10 & 5.218 \\
\hline \multirow[t]{2}{*}{ Tatil Köyü } & 1. Sinif & 69 & 55.434 & 12 & 6.199 \\
\hline & 2. Sinif & 9 & 2.890 & 13 & 8.332 \\
\hline Termal Tatil Köyü & 5 Yildıli & & & 1 & 310 \\
\hline Turizm Kompleksi & & 4 & 6.442 & - & - \\
\hline Müstakil Apart Otel & & 236 & 20.105 & - & - \\
\hline Termal M. Apart Otel & & 2 & 171 & - & - \\
\hline Butik Otel & & 101 & 7.740 & 42 & 3.153 \\
\hline Butik Termal Otel & & 2 & 124 & - & - \\
\hline Butik Tatil Villası & & 1 & 140 & - & - \\
\hline B Tipi Tatil Sitesi & & 2 & 236 & - & - \\
\hline Özel Tesis & & 412 & 26.487 & 23 & 1.170 \\
\hline Pansiyon & & 135 & 3.146 & - & - \\
\hline Motel & & 5 & 435 & 2 & 218 \\
\hline Golf Tesisi & & 3 & 1.348 & 1 & 228 \\
\hline Kirsal Turizm Tesisi & & 4 & 120 & 1 & 12 \\
\hline Kamping & & 6 & 1.125 & 7 & 2.287 \\
\hline Dağ Evi & & 4 & 359 & 4 & 177 \\
\hline Çiftlik Evi / Köy Evi & & 12 & 225 & 1 & 82 \\
\hline Oberj & & 3 & 970 & - & - \\
\hline Yayla Evi & & 2 & 90 & - & 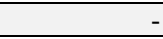 \\
\hline Toplam & & 4.218 & 1.020 .985 & 649 & 167.673 \\
\hline
\end{tabular}

Kaynak: Kültür ve Turizm Bakanlığı, 2020.

Grafik 1: Turistik Konaklama Tesislerinin Türlere Dağıllş̧ (\%)

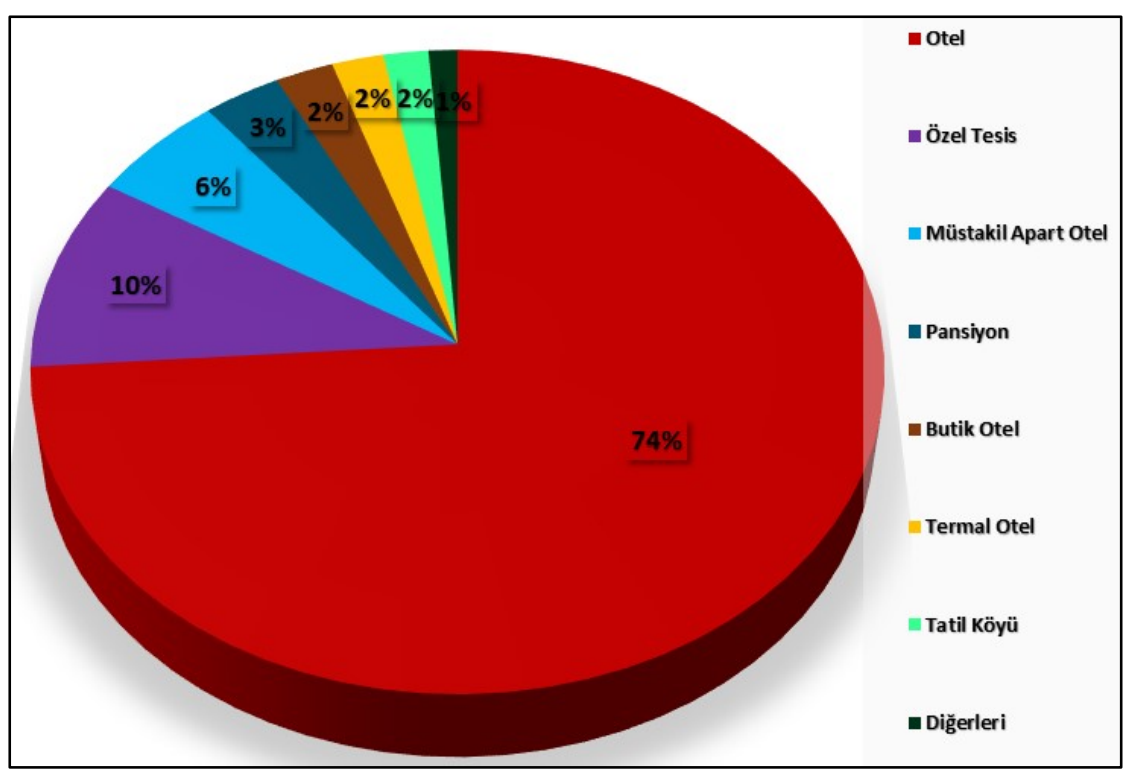

Kaynak: Kültür ve Turizm Bakanlığı, 2020.

Turkish Academic Research Review - Türk Akademik Araştırmalar Dergisi 


\section{Turizm İşletme Belgeli Konaklama Tesisleri}

Türkiye'de turizm işletme belgeli konaklama tesislerinin dağılış haritası (Harita 1 ve Tablo 3) incelendiğinde, bu tesislerin İstanbul başta olmak üzere Marmara (Bursa, Balıkesir, Çanakkale, Kocaeli), Ege (İzmir, Aydın, Muğla) ve Akdeniz (Antalya, Mersin, Adana, Hatay, Kahramanmaraş) bölgesinde bulunan illerde ayrıca Ankara ve Nevşehir ile Karadeniz kıyısındaki Trabzon'da yoğunlaştığı görülmektedir. Bu bölgeler aynı zamanda ülkede turistik faaliyetlerin de en fazla olduğu sahalara karşıl1k gelmektedir. Şüphesiz başta İstanbul ve Ankara olmak üzere bazı büyükşehirlerde bulunan turizm işletme belgeli konaklama tesislerinin turizm dışında, diğer sektörlere de hizmet verdiği anlaşılmaktadır.

Yukarıda belirtilen illeri takiben Doğu Anadolu'da Erzurum, Kars, Ağrı Güneydoğu Anadolu'da Diyarbakır, Mardin İç Anadolu'da Konya, Kayseri Karadeniz'de Samsun, Ordu, Giresun gibi daha birçok illerde turizm işletme belgeli tesisler yer almaktadır. Turizm işletme belgeli tesislerin son yıllarda kıyı alanlarının ve metropollerin dışında ülke geneline kısmen yayılmakta olduğu da görülmektedir. Nitekim Türkiye'de yatak arzına göre hala kıyı turizminin egemen olduğu, ancak diğer destinasyonların da kültür turizmi, şehir turizmi, iş ve kongre turizmi, gastronomi turizmi, termal turizm vb. türlerinin de gelişme sürecinde mekânsal çeşitlenmeyi kısmen de olsa arttırdığı söylenmektedir (Baykal, 2019: 399).

Tablo 3. Turizm İşletme Belgeli Konaklama Tesislerinin İllere Dağılışı (2020)

\begin{tabular}{|c|c|c|c|c|c|c|c|}
\hline $\begin{array}{l}\text { İlin } \\
\text { Adı }\end{array}$ & $\begin{array}{l}\text { Tesis } \\
\text { Sayısı }\end{array}$ & $\begin{array}{l}\text { İlin } \\
\text { Adı }\end{array}$ & $\begin{array}{l}\text { Tesis } \\
\text { Sayısı }\end{array}$ & $\begin{array}{l}\text { İlin } \\
\text { Adı }\end{array}$ & $\begin{array}{l}\text { Tesis } \\
\text { Sayısı }\end{array}$ & $\begin{array}{l}\text { İlin } \\
\text { Adı }\end{array}$ & $\begin{array}{l}\text { Tesis } \\
\text { Sayısı }\end{array}$ \\
\hline Adana & 45 & Çanakkale & 82 & Karabük & 30 & Osmaniye & 4 \\
\hline Adiyaman & 14 & Çankırı & 8 & Karaman & 8 & Rize & 16 \\
\hline A.Karahisar & 29 & Çorum & 9 & Kars & 34 & Sakarya & 21 \\
\hline Ağn1 & 32 & Denizli & 40 & Kastamonu & 24 & Samsun & 31 \\
\hline Aksaray & 17 & Diyarbakır & 32 & Kayseri & 23 & Siirt & 2 \\
\hline Amasya & 21 & Düzce & 17 & Kirıkkale & 3 & Sinop & 10 \\
\hline Ankara & 182 & Edirne & 28 & Kırklareli & 9 & Sivas & 16 \\
\hline Antalya & 807 & Elazığ & 20 & Kırşehir & 5 & Tekirdağ & 26 \\
\hline Ardahan & 14 & Erzincan & 14 & Kilis & 1 & Tokat & 18 \\
\hline Artvin & 12 & Erzurum & 22 & Kocaeli & 56 & Trabzon & 72 \\
\hline Aydın & 92 & Eskişehir & 37 & Konya & 38 & Tunceli & 5 \\
\hline Balıkesir & 95 & Gaziantep & 51 & Kütahya & 11 & Şanlıurfa & 18 \\
\hline Bartın & 13 & Giresun & 32 & Malatya & 16 & Şırnak & 6 \\
\hline Batman & 8 & Gümüşhane & 6 & Manisa & 30 & Uşak & 14 \\
\hline Bayburt & 2 & Hakkâri & 5 & K.Maraş & 56 & Van & 20 \\
\hline Bilecik & 7 & Hatay & 49 & Mardin & 25 & Yalova & 15 \\
\hline Bingöl & 3 & Iğdır & 3 & Muğla & 412 & Yozgat & 13 \\
\hline Bitlis & 9 & Isparta & 23 & Muş & 19 & Zonguldak & 16 \\
\hline Bolu & 26 & İçel Mersin & 64 & Nevşehir & 110 & & \\
\hline Burdur & 21 & İstanbul & 644 & Niğde & 6 & & \\
\hline Bursa & 84 & İzmir & 222 & Ordu & 37 & Toplam & 4.218 \\
\hline
\end{tabular}

Kaynak: Kültür ve Turizm Bakanlığı, 2020.

Diğer yandan son yıllarda otel, motel, pansiyon gibi geleneksel konaklama tesislerinin yanında termal tatil köyü, turizm kompleksi, butik termal otel, butik tatil villası, B tipi tatil sitesi, golf tesisi, kırsal turizm tesisi, kamping, dağ evi, çiftlik evi, oberj ve yayla evi gibi turistik konaklama tesisleri sayısında da önemli artışlar söz konusu olmaktadır. Dolayısıyla turizm faaliyetlerinde yeni alternatiflerle birlikte çeşitlilik arttıkça turistik konaklama tesislerinde de çeşitlilik artmaktadır. 


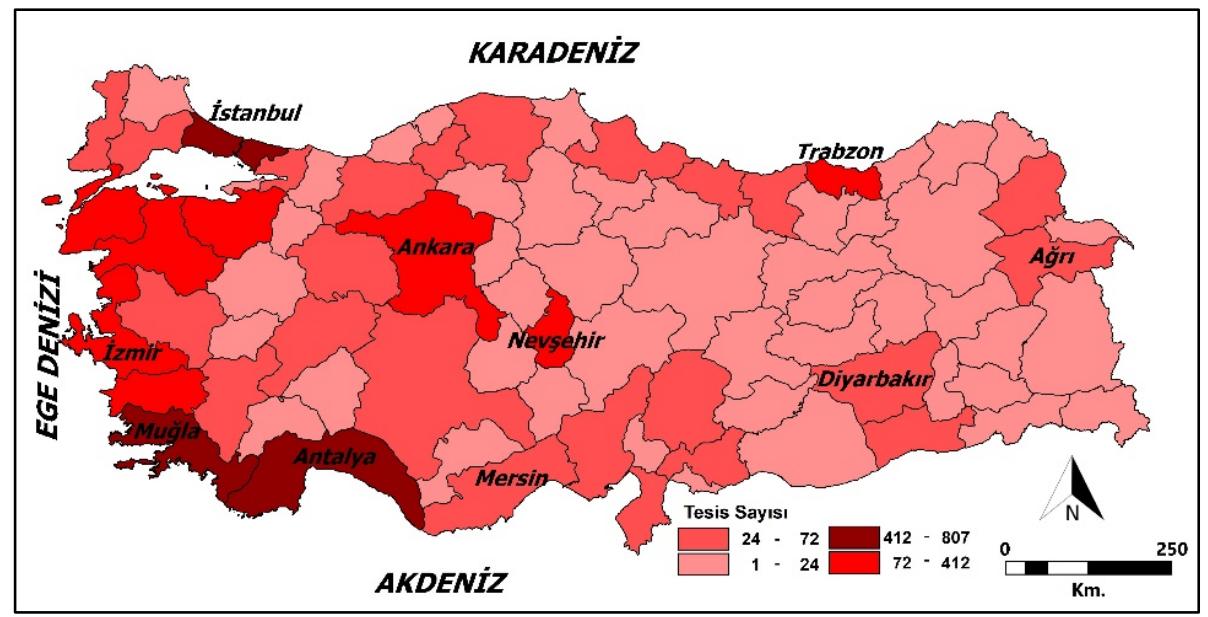

Harita 1. Turizm İşletme Belgeli Konaklama Tesislerinin İllere Dağılışı (2020)

Turizm, çeşitli aktiviteleri içinde barındıran ve çoğaltıcı etkiye sahip önemli ekonomik sektörlerden biridir. Bu nedenle her ilin turizm potansiyeli göz önünde bulundurularak uygun turizm faaliyetleri öne çıkarılmalı ve turistik konaklama tesislerinin hizmete girmesine destek verilmelidir. Gerçekten turizm, ekonomi ve istihdam konusunda oldukça büyük imkânlar sağladığından illerin kalkınmasında bundan yararlanmanın yolları aranmalı ve entegre turizm planlamaları yapılmalıdır.

Tablo 4. Turizm İşletme Belgeli Konaklama Tesislerinde Oda Sayısının İllere

Dağılışı (2020)

\begin{tabular}{|c|c|c|c|c|c|c|c|}
\hline $\begin{array}{l}\text { İlin } \\
\text { Adı }\end{array}$ & $\begin{array}{c}\text { Oda } \\
\text { Sayısı } \\
\end{array}$ & $\begin{array}{l}\text { İlin } \\
\text { Adı }\end{array}$ & $\begin{array}{c}\text { Oda } \\
\text { Sayısı } \\
\end{array}$ & $\begin{array}{l}\text { İlin } \\
\text { Adı }\end{array}$ & $\begin{array}{c}\text { Oda } \\
\text { Sayısı } \\
\end{array}$ & $\begin{array}{l}\text { İlin } \\
\text { Adı }\end{array}$ & $\begin{array}{c}\text { Oda } \\
\text { Sayısı } \\
\end{array}$ \\
\hline Adana & 3633 & Çanakkale & 3569 & Karabük & 701 & Osmaniye & 263 \\
\hline Adiyaman & 816 & Çankırı & 316 & Karaman & 476 & Rize & 999 \\
\hline A.Karahisar & 3655 & Çorum & 515 & Kars & 1275 & Sakarya & 2054 \\
\hline Ağr1 & 1081 & Denizli & 3579 & Kastamonu & 869 & Samsun & 2021 \\
\hline Aksaray & 814 & Diyarbakır & 2414 & Kayseri & 1920 & Siirt & 187 \\
\hline Amasya & 728 & Düzce & 710 & Kırıkkale & 147 & Sinop & 300 \\
\hline Ankara & 14530 & Edirne & 1269 & Kırklareli & 595 & Sivas & 818 \\
\hline Antalya & 214856 & Elazığ & 1039 & Kırşehir & 478 & Tekirdağ & 1712 \\
\hline Ardahan & 359 & Erzincan & 607 & Kilis & 46 & Tokat & 828 \\
\hline Artvin & 575 & Erzurum & 1392 & Kocaeli & 4223 & Trabzon & 3953 \\
\hline Aydın & 13840 & Eskişehir & 2394 & Konya & 3467 & Tunceli & 136 \\
\hline Balıkesir & 5485 & Gaziantep & 4273 & Kütahya & 581 & Şanlıurfa & 1164 \\
\hline Bartın & 442 & Giresun & 948 & Malatya & 1229 & Şırnak & 647 \\
\hline Batman & 555 & Gümüşhane & 267 & Manisa & 1622 & Uşak & 552 \\
\hline Bayburt & 138 & Hakkâri & 198 & K.Maraş & 2053 & Van & 1095 \\
\hline Bilecik & 344 & Hatay & 2573 & Mardin & 1216 & Yalova & 1353 \\
\hline Bingöl & 177 & Iğdır & 149 & Muğla & 51316 & Yozgat & 699 \\
\hline Bitlis & 429 & Isparta & 1167 & Muş & 575 & Zonguldak & 873 \\
\hline Bolu & 2033 & İçel Mersin & 4563 & Nevşehir & 5550 & & \\
\hline Burdur & 516 & İstanbul & 64165 & Niğde & 364 & & \\
\hline Bursa & 6283 & İzmir & 19949 & Ordu & 1654 & Toplam & 487.376 \\
\hline
\end{tabular}

Kaynak: Kültür ve Turizm Bakanlığı, 2020.

Turizm işletme belgeli konaklama tesislerinde oda sayısının illere (Tablo 4) dağılışında, ilk sırayı 214.856 oda sayısıyla Antalya almaktadır. Daha sonra sırasıyla İstanbul (64.165), Muğla (51.316), İzmir (19.949), Ankara (14.530) ve Aydın

Turkish Academic Research Review - Türk Akademik Araştırmalar Dergisi 
(13.840) gelmektedir. Oda sayısının illere dağılışı işletme sayısının dağılışıyla doğru orantılı bir şekilde artmaktadır. Dolayısıyla tesis sayısının fazla olduğu illerde oda sayısı da fazla olmaktadır.

Turizm işletme belgeli konaklama tesislerinde yatak sayısının illere dağılışı (Tablo 5) ele alındığında ise, en fazla yatak sayısının 463.194 ile Antalya'da yer aldığ 1 ayırt edilmektedir. Daha sonra sirasıyla İstanbul (129.242), Muğla (109.388), İzmir (41.026), Aydın (29.167) ve Ankara (29.079) illeri gelmektedir. Bu değerler ülke toplamı ile mukayese edildiğinde, Antalya ili tek başına yaklaşık \%45, adı geçen 6 il (Antalya, İstanbul, Muğla, İzmir, Aydın, Ankara) de 801.096 yatak kapasitesi ile yaklaşık \%78'e sahip olduğu anlaşılır. Genellikle tesis sayısının fazla olduğu illerde yatak sayısı da fazla olmaktadır. Ancak bazı illerde tesis sayısı ile yatak sayısı arasında doğru bir orantı da mevcut değildir. Örneğin daha az tesise sahip olan Aydın ili yatak sayısında daha fazla tesise sahip olan Ankara'yı geçmektedir.

Tablo 5. Turizm İşletme Belgeli Konaklama Tesislerinde Yatak Sayısının İllere

Dağılışı (2020)

\begin{tabular}{|l|r|l|r|l|r|l|r|}
\hline \multicolumn{1}{|c|}{$\begin{array}{c}\text { İlin } \\
\text { Adı }\end{array}$} & \multicolumn{1}{|c|}{$\begin{array}{c}\text { Yatak } \\
\text { Sayısı }\end{array}$} & \multicolumn{1}{|c|}{$\begin{array}{c}\text { İlin } \\
\text { Adı }\end{array}$} & $\begin{array}{c}\text { Yatak } \\
\text { Sayısı }\end{array}$ & \multicolumn{1}{c|}{$\begin{array}{c}\text { İlin } \\
\text { Adı }\end{array}$} & $\begin{array}{c}\text { Yatak } \\
\text { Sayısı }\end{array}$ & \multicolumn{1}{c|}{$\begin{array}{c}\text { İlin } \\
\text { Adı }\end{array}$} & $\begin{array}{c}\text { Yatak } \\
\text { Sayısı }\end{array}$ \\
\hline Adana & 7327 & Çanakkale & 7237 & Karabük & 1312 & Osmaniye & 523 \\
\hline Adıyaman & 1624 & Çankırı & 623 & Karaman & 964 & Rize & 2030 \\
\hline A.Karahisar & 7628 & Çorum & 994 & Kars & 2579 & Sakarya & 4133 \\
\hline Ağrı & 2083 & Denizli & 7171 & Kastamonu & 1760 & Samsun & 4061 \\
\hline Aksaray & 1640 & Diyarbakır & 4786 & Kayseri & 3865 & Siirt & 374 \\
\hline Amasya & 1459 & Düzce & 1441 & Kırıkkale & 294 & Sinop & 618 \\
\hline Ankara & 29079 & Edirne & 2475 & Kırklareli & 1185 & Sivas & 1648 \\
\hline Antalya & 463194 & Elazı̆ & 2116 & Kırşehir & 989 & Tekirdağ & 3397 \\
\hline Ardahan & 634 & Erzincan & 1170 & Kilis & 86 & Tokat & 1633 \\
\hline Artvin & 1152 & Erzurum & 2806 & Kocaeli & 8535 & Trabzon & 8172 \\
\hline Aydın & 29167 & Eskişehir & 4755 & Konya & 6968 & Tunceli & 272 \\
\hline Balıkesir & 11155 & Gaziantep & 8528 & Kütahya & 1169 & Şanlurfa & 2346 \\
\hline Bartın & 886 & Giresun & 1862 & Malatya & 2447 & Şırnak & 1296 \\
\hline Batman & 1103 & Gümüşhane & 526 & Manisa & 3263 & Uşak & 1100 \\
\hline Bayburt & 271 & Hakkâri & 396 & K.Maraş & 4095 & Van & 2256 \\
\hline Bilecik & 655 & Hatay & 5202 & Mardin & 2429 & Yalova & 2790 \\
\hline Bingöl & 374 & Iğdır & 270 & Muğla & 109388 & Yozgat & 1462 \\
\hline Bitlis & 867 & Isparta & 2358 & Muş & 1247 & Zonguldak & 1766 \\
\hline Bolu & 4234 & Mersin & 9460 & Nevşehir & 11712 & & \\
\hline Burdur & 964 & İstanbul & 129242 & Niğde & 731 & & \\
\hline Bursa & 12808 & İzmir & 41026 & Ordu & 3342 & Toplam & $\mathbf{1 . 0 2 0 . 9 8 5}$ \\
\hline
\end{tabular}

Kaynak: Kültür ve Turizm Bakanlığı, 2020.

İllerde bulunan tesis, oda ve yatak sayısının karşılaştırılması bazı ilginç sonuçlar vermektedir. Nitekim Türkiye'de faaliyet gösteren 4.218 turizm işletme belgeli konaklama tesisinde toplam 487.376 oda ve 1.020 .985 yatak mevcuttur. Buna göre ülkede yaklaşık tesis başına 115 oda ve 241 yatak düşmektedir. Antalya ilindeki 807 konaklama tesisinde 214.856 oda ve 463.194 yatak bulunmakta ve ortalama tesis başına 266 oda ve 573 yatak düşmektedir. İstanbul ilindeki 644 konaklama tesisinde ise 64.165 oda ve 129.242 yatak olup tesis başına yaklaşık 100 oda ve 200 yatak düşmektedir. Aynı şekilde Aydın'da tesis (92) başına 150 oda ve 317 yatak, Ankara'da tesis (182) başına 80 oda ve 160 yatak düşmektedir. Bu değerlerin ortaya koyduğu gibi konaklama tesislerinin büyüklüğü illere göre önemli farklılıklar arz etmektedir. Özellikle Antalya, Aydın, Muğla gibi turistik bölgelerde bulunan tesisler çok daha büyük kapasiteye sahiptir. Böylelikle turizm faaliyetleri, tesis sayısının dağılışı kadar tesislerin türünü ve kapasitelerini de etkilediği anlaşılmaktadır. 
Diğer taraftan konaklama tesislerinin aydınlanması, ısınması, havalandırılması yeterli düzeyde ve çevreye uyumlu şekilde olmalıdır. Bunun dışında müşterilerin temel ihtiyaçlarını karşılayacak, eğitimli, yetkin personelin bulunması, farklı dillerde bilgilendirmenin yapılması, hijyen ve temizlik kurallarına titizlikle uyulması, oda ve yatakların müşteri ihtiyaçlarını karşılayabilecek şekilde dizayn edilmesi, güvenlik tedbirlerinin alınması, fiziki engelli müşterilere oda, yatak ve asansörlerin uygun hale getirilmesi gerekmektedir. Ayrıca bu sıralanan kriterlerin yanında turizm türüne göre de ek tedbirler alınmalıdır. Kış turizmi, yayla turizmi, kültür turizmi, doğa turizmi gibi turizm türlerine özgü hizmet ve standartlar işletmeler tarafından yerine getirilmelidir. Turizmin geliştirilmesi ve gelirlerinin artması açısından konaklama ve müşteri memnuniyeti oldukça önemlidir.

Bakanlık işletme belgeli turistik konaklama tesisleri türlerine göre sınıflandırılarak illere dağılışı aşağıda verilmiştir. Burada ele alınan otel, motel, tatil köyü, pansiyon, kamping ve hosteller Kültür ve Turizm Bakanlığı tarafından asli konaklama tesisleri olarak belirlenmiştir.

\section{Otel}

Turistlerin geceleme, yeme-içme ve dinlenme ihtiyaçlarını karşılayan tesislere veya işletmelere otel adı verilmektedir (Doğanay, 2001: 525). Bu tesisler fonksiyon olarak tarihi hanların yerini almıştır. Tarihi dönemlerde özellikle Anadolu'da hanlar yolcuların çeşitli ihtiyaçlarını karşılayan sosyal tesisler olarak işlev görmüşlerdir. Daha sonra otel olarak bu hizmeti veren tesisler daha modern bir yapıda inşa edilmişlerdir. Bununla birlikte burada çalışan personel de daha donanımlı ve profesyonel niteliklere sahip olmuştur.

Türkiye'de ticari konaklamanın geçmişi oldukça eskidir. Konaklama ihtiyacı, han ve kervansaray gibi sosyal tesislerde karşılanmıştır. Roma ve Bizans döneminde de hanlara benzer ticari konaklama tesisleri faaliyet göstermiştir. Fakat Selçuklu ve Osmanlı dönemlerinde işlevlerini daha da geliştirerek hizmet sunmuşlardır. Örneğin Horozlu Han, Sultan Hanı, Vezirhan, Hekimhan, Taşhan, Deliller Hanı, Obruk Hanı, Kızılören Hanı, Zazadin Hanı vb. Anadolu'daki onlarca önemli hanlardan bazılarıdır (Foto 1). Han ve kervansarayların işlevlerini devam ettirmeleri amacıyla çeşitli vakıflar da kurulmuştur.

Türkiye'de faaliyete giren ilk modern turistik otel İstanbul Beyoğlu'nda bulunan Pera Palas'tır. $\mathrm{Bu}$ otel 1895 'te açılmıştır. Tanzimat sonrası dönemde etkili batılılaşma hareketleri her alanda olduğu gibi turistik konaklamada da kendini göstermiştir. Ancak, bu alandaki çalışmalar kısıtlı kaldığından yaygınlaşamamıştır. Cumhuriyetin ilk yıllarında, yeni kurulan devletin temel kurumlarına öncelik verilmiştir. Turizm, temel ihtiyaçlar karşılandıktan sonra gerçekleştirilen bir faaliyet olduğundan sektörün gelişmesi zaman almıştır. Dünyada kısa zaman sürecinde iki büyük savaşın yaşanması bir yıkım meydana getirmiştir. Dolayısıyla turizm ve konaklamayla ilgili gelişmeler İkinci Dünya Savaşı'nın sonrasına ötelenmiştir.

Türkiye'de 1955'te devlet eliyle Turizm Bankası ve Emekli Sandığı kurulmuş ve turistik konaklama tesislerinin inşasında finansman desteği sağlanmıștır. 1959'da açılan İstanbul Hilton Oteli, Cumhuriyet döneminin ilk modern oteli özelliğini taşımaktadır (Doğanay, 2001: 525). Turizm Bankası'nın desteklediği TURBAN projesiyle ülkenin özellikle batı bölgelerinde önemli turizm yatırımları yapılmıştır.

Turkish Academic Research Review - Türk Akademik Araştırmalar Dergisi 


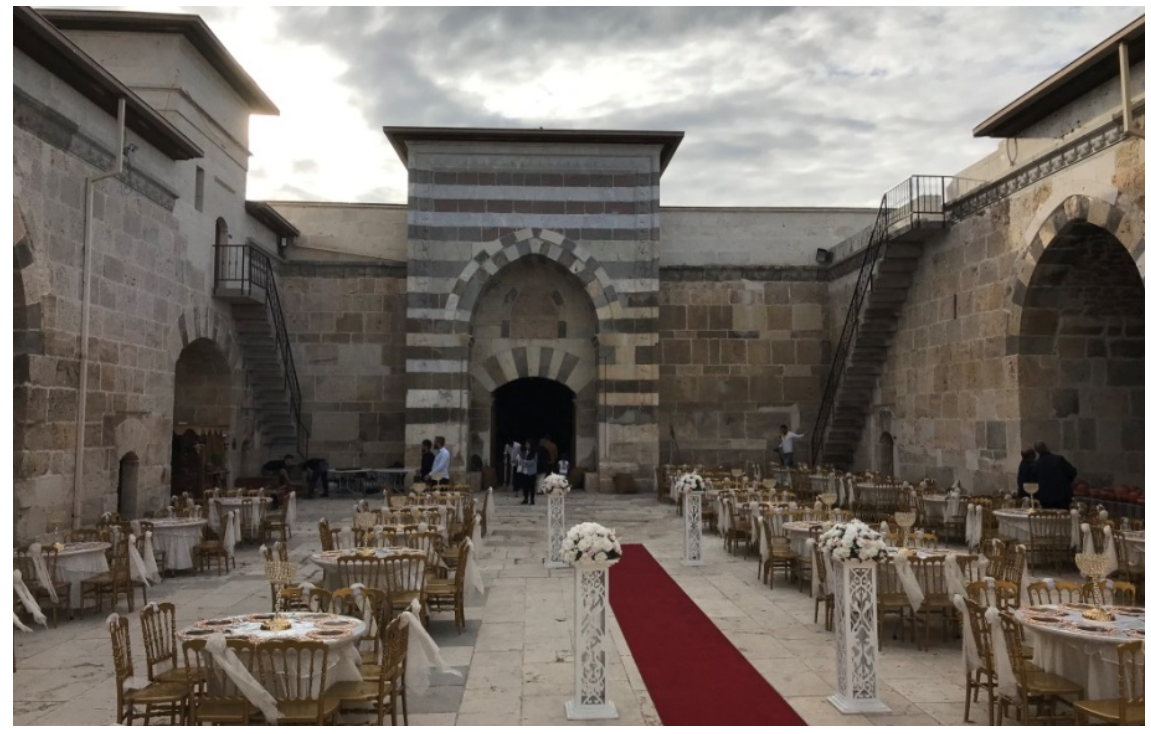

Foto 1. Konya-Aksaray yolunda inşa edilen Zazadin Hanı (13. yüzyıl).

Kültür ve Turizm Bakanlığı tarafından oteller çeşitli kriterler dikkate alınarak sınıflara ayrılmıştır. Otel, apart otel, butik otel, butik termal otel, müstakil apart otel, termal müstakil apart otel ve termal otel şeklinde sınıflamalar yapılmıştır. Oteller kendi içinde bir yıldızdan beş yıldıza kadar sınıflanmıştır. Bu sınıflandırma bakanlığın belirlediği kriterlere göre yapılmıştır. Harita 2'de 5 yıldızlı otellerin illere dağılışı verilmiştir. Buna göre 5 yıldızlı oteller Türkiye'nin batı, güneybatı ve güney kıyıları ile İstanbul'da yoğunluk kazanmıştır.

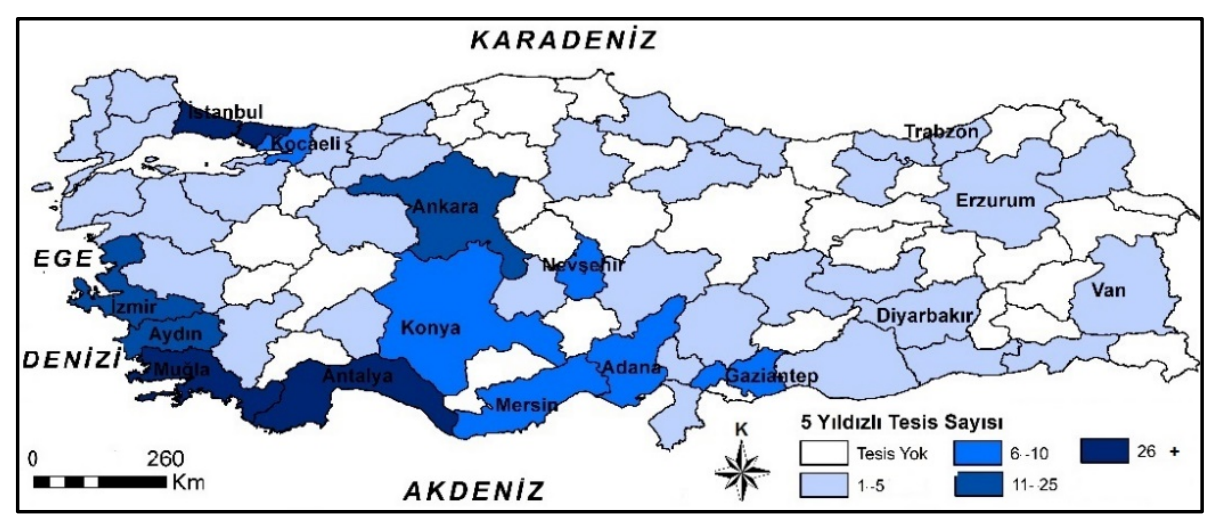

Harita 2. Türkiye'de 5 Yıldızlı Otellerin İllere Dağılışı (2020)

5 yıldızlı otellerin Türkiye'deki dağılışı düzenli değildir. 42 ilde 5 yıldızlı en az bir otel mevcutken 39 ilde henüz böyle tesis inşa edilmemiştir. Bu itibarla Türkiye'nin iller düzeyinde yaklaşık yarısında, özellikle de Sivas, Afyonkarahisar ve Kütahya gibi illerinde 5 yıldızlı otelin olmaması dikkati çekmektedir. Aynı şekilde 14 ilde ancak bir adet 5 yıldızlı otel bulunmaktadır (Tablo 6). Bu verilere göre, 5 yıldızlı otellerin ülke sathında düzenli bir dağılış arz etmediği görülmektedir. Şüphesiz bunda arz talep ilişkisi ile yerel müteşebbislerin yeterli olmamasının da rolü söz konusudur. 
Tablo 6. Türkiye'de 5 Yıldızlı Otellerin İllere Dağılışı (2020)

\begin{tabular}{|l|r|r|r|l|r|r|r|}
\hline $\begin{array}{c}\text { İlin } \\
\text { Adı }\end{array}$ & $\begin{array}{r}\text { Otel } \\
\text { Sayısı }\end{array}$ & $\begin{array}{r}\text { Oda } \\
\text { Sayısı }\end{array}$ & $\begin{array}{r}\text { Yatak } \\
\text { Sayısı }\end{array}$ & $\begin{array}{r}\text { Illin } \\
\text { Adı }\end{array}$ & $\begin{array}{r}\text { Otel } \\
\text { Sayısı }\end{array}$ & $\begin{array}{r}\text { Oda } \\
\text { Sayısı }\end{array}$ & $\begin{array}{r}\text { Yatak } \\
\text { Sayısı }\end{array}$ \\
\hline Adana & 7 & 1272 & 2548 & Kars & 2 & 234 & 512 \\
\hline Aksaray & 1 & 101 & 202 & Kayseri & 3 & 635 & 1272 \\
\hline Ankara & 24 & 4924 & 9922 & Kırklareli & 1 & 126 & 252 \\
\hline Antalya & 342 & 138317 & 299187 & Kocaeli & 7 & 1228 & 2540 \\
\hline Aydın & 19 & 6302 & 13142 & Konya & 8 & 1742 & 3542 \\
\hline Balıkesir & 3 & 636 & 1296 & Malatya & 3 & 543 & 1090 \\
\hline Bolu & 4 & 636 & 1332 & Manisa & 1 & 110 & 227 \\
\hline Bursa & 4 & 639 & 1278 & K.Maraş & 2 & 285 & 570 \\
\hline Çanakkale & 2 & 438 & 946 & Mardin & 2 & 347 & 694 \\
\hline Çorum & 1 & 217 & 434 & Muğla & 62 & 17566 & 37872 \\
\hline Denizli & 1 & 126 & 256 & Nevşehir & 6 & 1338 & 2672 \\
\hline Diyarbakır & 3 & 424 & 850 & Ordu & 3 & 404 & 808 \\
\hline Düzce & 1 & 184 & 378 & Osmaniye & 1 & 100 & 200 \\
\hline Edirne & 1 & 160 & 332 & Rize & 3 & 542 & 1114 \\
\hline Elazı̆̆ & 1 & 110 & 222 & Sakarya & 5 & 1191 & 2386 \\
\hline Erzurum & 2 & 405 & 822 & Samsun & 3 & 505 & 1032 \\
\hline Eskişehir & 3 & 467 & 933 & Tekirdağ & 3 & 451 & 914 \\
\hline Gaziantep & 7 & 1325 & 2656 & Tokat & 1 & 143 & 288 \\
\hline Gümüşhane & 1 & 106 & 212 & Trabzon & 4 & 860 & 1747 \\
\hline Hatay & 2 & 345 & 710 & Şanlıurfa & 3 & 429 & 858 \\
\hline Isparta & 1 & 142 & 282 & Şırnak & 2 & 398 & 798 \\
\hline İçel Mersin & 7 & 1265 & 2620 & Van & 2 & 324 & 650 \\
\hline İstanbul & 11 & 29383 & 59277 & Yalova & 1 & 120 & 240 \\
\hline İzmir & 20 & 5913 & 12324 & Zonguldak & 1 & 204 & 418 \\
\hline & & & & $\mathbf{7 0 4}$ & $\mathbf{2 2 3 . 6 6 2}$ & $\mathbf{4 7 4 . 8 5 7}$ \\
\hline
\end{tabular}

Kaynak: Kültür ve Turizm Bakanlığı, 2020.

Türkiye'de Antalya, Muğla, İstanbul, Ankara, İzmir, Aydın 5 yıldızlı otellerin en yoğun olduğu illerdir (Grafik 2, Foto 2). İkinci grupta Adana, Mersin, Gaziantep, Kocaeli, Konya ve Nevşehir yer almaktadır. Dolayısıyla deniz turizminin geliştiği iller ile üç büyükşehir ve Ürgüp - Göreme yöresi 5 yıldızlı otellerin yoğunlaştığ alanlardır (Tablo 6). 5 yıldızlı otellerin bu dağılış düzeni, turizm ve nitelikli konaklama tesisleri arasındaki ilişkiyi açık bir şekilde yansıtan önemli bir özelliktir.

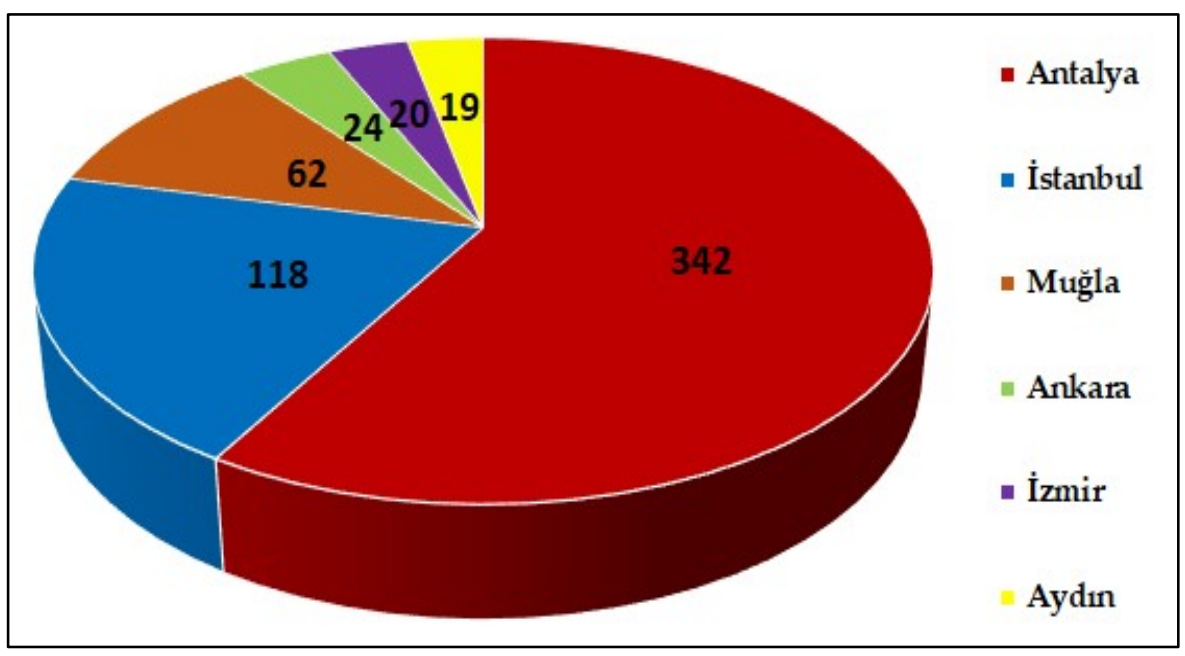

Grafik 2: On ve Daha Fazla Sayıda 5 Yıldızlı Otele Sahip Olan İller (2020) 


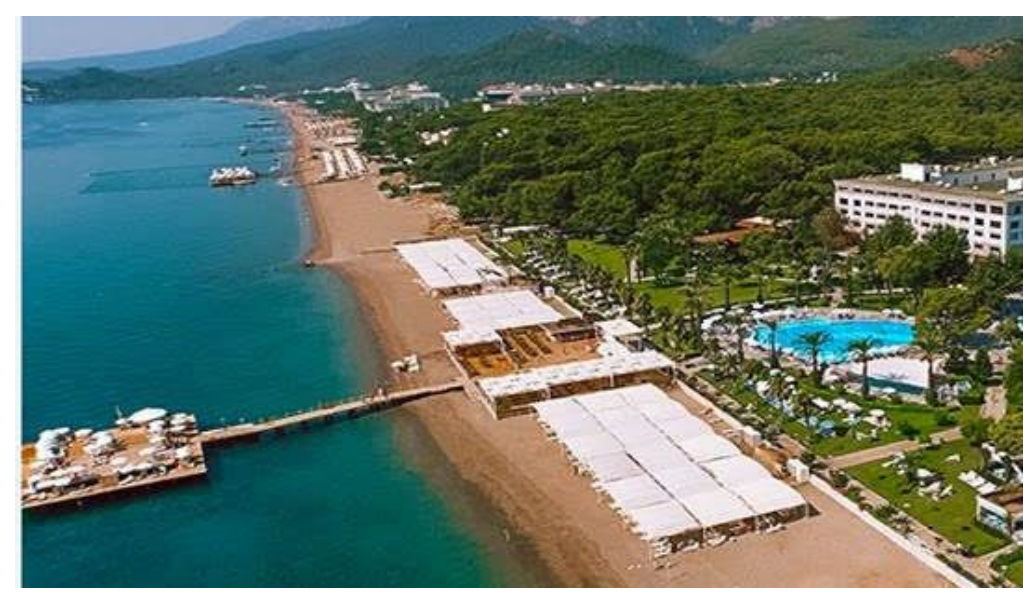

Foto 2. Antalya'da yer alan 5 yıldızlı otelden bir görünüm.

Termal Oteller: Oteller içinde özellikle termal otellerin ayrı bir önemi vardır. Gerçekten Türkiye tektonik yapısı nedeniyle termal kaynaklar bakımından Avrupa ve Dünya'nın önde gelen ülkelerinin başında gelmektedir. Kaplıca adı altında geleneksel bir yönü de bulunan termal tesislerin son dönemde önemli bir gelişme gösterdiği dikkati çekmektedir. Türkiye'nin halen 25 ilinde farklı düzeyde $(3,4,5$ yıldız) 90 adet termal oteller yer almaktadır. Bu otellerde 14.828 oda ve 31.235 adet yatak mevcuttur (Tablo 7). Ülkenin termal turizm potansiyeli göz önüne alındığında bu değerler çok yetersiz kalmaktadır.

Tablo 7. Türkiye'de Termal Otellerin İllere Dağılışı (2020)

\begin{tabular}{|l|r|r|r|l|r|r|r|}
\hline \multicolumn{1}{|c|}{$\begin{array}{c}\text { İlin } \\
\text { Adı }\end{array}$} & $\begin{array}{r}\text { Otel } \\
\text { Sayısı }\end{array}$ & $\begin{array}{r}\text { Oda } \\
\text { Sayısı }\end{array}$ & $\begin{array}{r}\text { Yatak } \\
\text { Sayısı }\end{array}$ & $\begin{array}{r}\text { İlin } \\
\text { Adı }\end{array}$ & $\begin{array}{r}\text { Otel } \\
\text { Sayısı }\end{array}$ & $\begin{array}{r}\text { Oda } \\
\text { Sayısı }\end{array}$ & $\begin{array}{r}\text { Yatak } \\
\text { Sayısı }\end{array}$ \\
\hline Afyon (3Y) & 1 & 160 & 320 & Hatay (5Y) & 1 & 252 & 504 \\
\hline Afyon (5Y) & 10 & 2986 & 6264 & İstanbul (4Y) & 1 & 80 & 160 \\
\hline Amasya (3Y) & 2 & 108 & 222 & İzmir (4Y) & 3 & 420 & 880 \\
\hline Amasya (5Y) & 1 & 98 & 196 & İzmir (5Y) & 6 & 2102 & 4335 \\
\hline Ankara (4Y) & 4 & 274 & 552 & Kırşehir (4Y) & 2 & 330 & 690 \\
\hline Ankara (5Y) & 4 & 919 & 1988 & Kütahya (4Y) & 3 & 203 & 412 \\
\hline Balıkesir (3Y) & 2 & 123 & 243 & Manisa (4Y) & 1 & 123 & 292 \\
\hline Balıkesir (4Y) & 2 & 214 & 455 & Muğla (4Y) & 2 & 615 & 1333 \\
\hline Balıkesir (5Y) & 2 & 367 & 747 & K.Maraş (3Y) & 1 & 23 & 51 \\
\hline Bolu (4Y) & 1 & 77 & 154 & K.Maraş (5Y) & 1 & 132 & 274 \\
\hline Bursa (3Y) & 3 & 210 & 466 & Nevşehir (3Y) & 1 & 60 & 120 \\
\hline Bursa (4Y) & 2 & 149 & 298 & Nevşehir (4Y) & 2 & 217 & 510 \\
\hline Bursa (5Y) & 6 & 1046 & 2126 & Nevşehir (5Y) & 1 & 230 & 860 \\
\hline Çanakkale (3Y) & 1 & 40 & 80 & Niğde (4Y) & 1 & 67 & 137 \\
\hline Çanakkale (4Y) & 1 & 55 & 110 & Samsun (3Y) & 1 & 60 & 120 \\
\hline Çankırı (3Y) & 1 & 29 & 58 & Samsun (4Y) & 1 & 78 & 157 \\
\hline Denizli (3Y) & 1 & 132 & 264 & Tunceli (3Y) & 1 & 18 & 36 \\
\hline Denizli (4Y) & 1 & 129 & 258 & Yalova (3Y) & 2 & 43 & 110 \\
\hline Denizli (5Y) & 7 & 1660 & 3326 & Yalova (4Y) & 3 & 545 & 1096 \\
\hline Diyarbakır (4Y) & 1 & 82 & 170 & Yalova (5Y) & 1 & 90 & 208 \\
\hline Eskişehir (3Y) & 1 & 35 & 70 & Yozgat (5Y) & 1 & 247 & 583 \\
\hline 3Y: 3 Yıldızlı 4Y: 4 Yıldızlı 5Y: 5Yıldızlı & Toplam & $\mathbf{9 0}$ & $\mathbf{1 4 . 8 2 8}$ & $\mathbf{3 1 . 2 3 5}$ \\
\hline
\end{tabular}

Kaynak: Kültür ve Turizm Bakanlığı, 2020. 
Termal otellerin illere dağılışı harita 3 'te gösterilmiştir. Bu haritada diğer turizm türlerine göre konaklama tesislerinde daha farklı bir dağılım ortaya çıkmaktadır. Buradaki dağılım, özellikle fay hatlarına ve sıcak su kaynaklarına paralellik arz etmektedir. Termal otel sayısı bakımından ise Afyonkarahisar, Denizli, İzmir, Bursa ilk sırada yer almaktadır. 5 yıldızlı termal otellerde 10 adet otelle Afyonkarahisar ili açık ara önde gelmektedir. Sonra Denizli 7, Bursa 6, İzmir 6 ve Ankara 4 adet 5 y1ldılı termal otelle takip etmektedir (Foto 3).

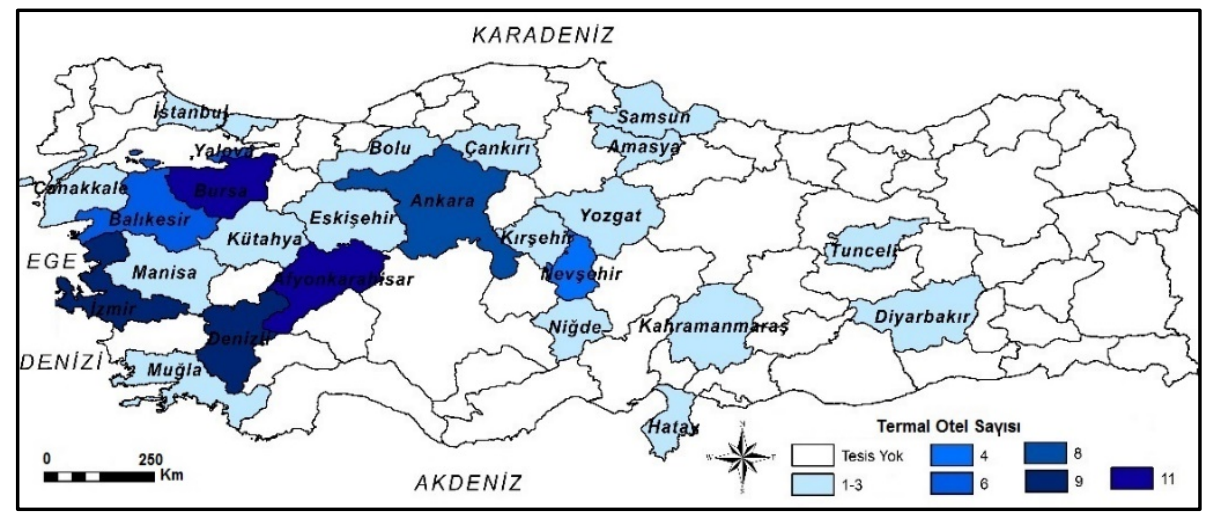

Harita 3. Türkiye'de 3, 4 ve 5 Yıldızlı Termal Otellerin İllere Dağılışı (2020)
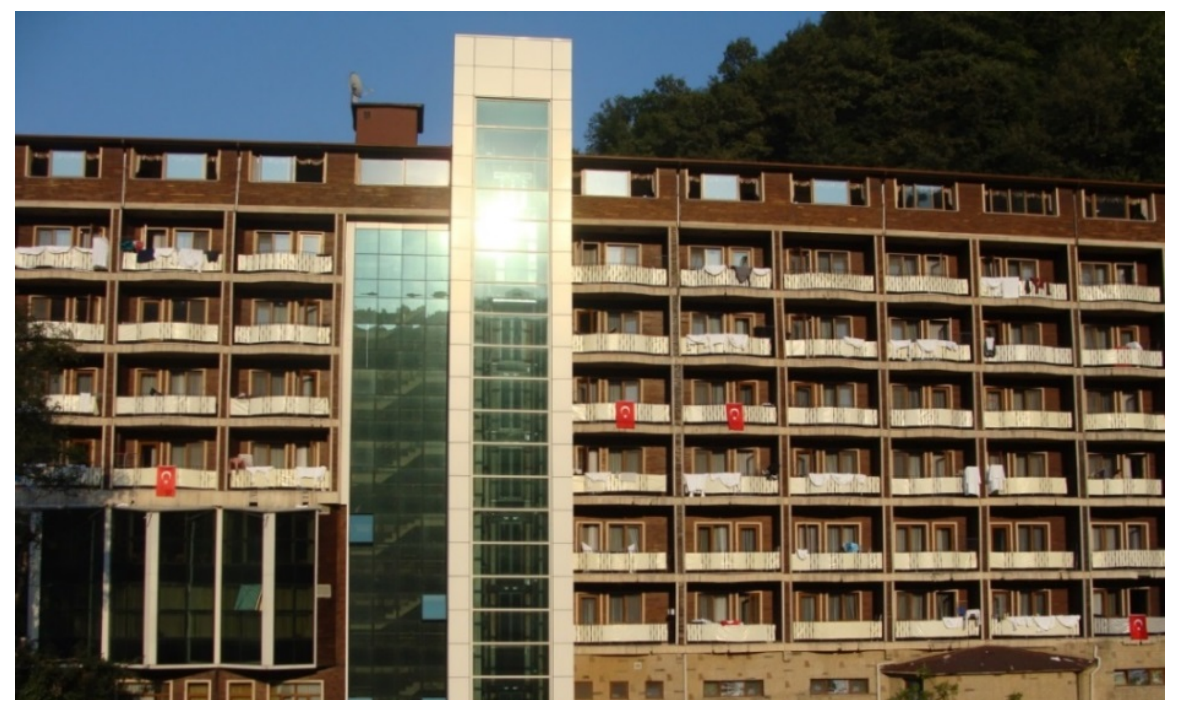

Foto 3. Bursa Oylat Kaplıcaları'nda 5 yıldızlı bir termal otel.

Öte yandan 3, 4 ve 5 yıldızlı toplam otel sayısı bakımından değerlendirildiğinde, Balıkesir 12, Bursa 12, Denizli 12, Nevşehir 12 ve Yalova ili 12 otele sahip bulunmaktadır. $\mathrm{Bu}$ illeri 9 adetle Ankara ve İzmir, 8 adetle Amasya ve Kahramanmaraş, 7 adetle Çanakkale ve Samsun illeri takip etmektedir. Bu oteller termal kaynakların dağılışına bağlı olarak illerin belirli ilçelerinde yoğunluk kazandığı görülmektedir. Örneğin Balıkesir ilinin Gönen, Ankara'nın Kızılcahamam ve Yalova'nın da Termal ilçesinde daha çok tesis yer almaktadır.

Turkish Academic Research Review - Türk Akademik Araştırmalar Dergisi 


\section{Motel}

Motel, şehir dışı otel olarak tanımlanır (Özgüç, 2017: 116). Ana yollar üzerinde yer aldığından dolayı yol boyu turistik konaklama tesisleri grubuna dâhil edilmektedir. Fonksiyon bakımından hanlar otellere karşılık gelirken moteller kervansaraylara karşılık gelmektedir. Ulaşım hatları üzerinde dağılış gösterdiklerinden yol ağı ile bir ilişki söz konusudur. Motorlu araçla seyahat edenlerin yolculuk sırasında dinlenme ihtiyaçlarını karşılamaktadır (Doğanay, 2001: 532).

Moteller, şehir dışında sakin bir ortamda bulunması, otopark sorunun olmaması ve odaların sade olmakla birlikte günlük ihtiyaçlara cevap verecek şekilde dizaynı gibi nedenlerle tercih edilmektedir (Barutçugil, 1989: 53). Motor kelimesinin ilk hecesi ve hotel kelimesinin ikinci hecesinin birleşmesiyle motel terimi ortaya çıkmıştır. (Doğanay, 2001: 531). İlk zamanlarda sadece yatak hizmeti veren moteller daha sonra yeme-içme, otopark hizmeti vermeye başlamışlardır. Rekabetin artmasıyla birlikte hizmet ve kalite artmış, çok katlı moteller inşa edilmiştir (Aktaş, 2002: 34).

Geçmiş yıllara göre motel sayısında azalma göze çarpmaktadır. 2007 yılında 18 adet motel varken 2020 yılında sadece 5 adet bakanlık işletmeli motel bulunmaktadır. Belediye işletme belgeli motel sayısı çok daha fazladır. 2020 yılı sonu itibariyle Türkiye'de Adana, Ankara, Denizli, Elazığ ve Mersin'de birer olmak üzere toplam 5 motel vardır. $\mathrm{Bu}$ tesisler toplam 214 odaya ve 435 yatak kapasitesine sahiptir. 218 yatak kapasiteli 2 tesisin inşası devam etmektedir.

Motellerde en az 10 oda bulunmalıdır. Tesislerin ulaşım güzergâhları üzerinde rahatlıkla görülmeleri açısından yön işaretlerinin uygun yerlerde ve görünür olması gerekmektedir. Ayrıca moteller, yol güzergâhları üzerinde yer aldıkları için gürültü ile ilgili önlemler de alınmalıdır.

\section{Pansiyon}

Pansiyonlar, yemek hizmetlerinin işletme tarafından sağlandığı veya müşterinin yemek yapma imkânına sahip olduğu konaklama tesisleridir. Yine yönetimi basit ve en az beş odadan oluşurlar (Resmi Gazete, 2019: 109). Pansiyonlar diğer konaklama tesislerinden farklı olarak bir aile ortamına sahiptir. Kesintisiz yeme-içme hizmetleri ve istenilen sürede konaklama imkânı sağlanmaktadır. Otel sayısının yetersiz olduğu özellikle küçük yerleşmelerde ucuz olmasının yanında aile işletmeleri için de önemli bir gelir kaynağını teşkil etmektedir (Barutçugil, 1989: 54). Pansiyonlar özellikle yeme-içme hizmetini sunabilecek veya müşterinin bu ihtiyacını karşılayabilecek asgari niteliğe sahip olmalıdır. Mutfak, mevsimlik dönemler için yeterli bir salon, girişte bir hol, ilk yardım ve emanet hizmeti verilmektedir.

Türkiye'de pansiyon kelimesi öğrenci yurdu anlamında kullanılmakla birlikte günümüzde turistik tesis anlamında da kullanılmaktadır. Kişilere ait evlerin tamamı veya bir kısmının turistik amaçla işletilmesi pansiyonculuk olarak tanımlanmaktadır. $\mathrm{Bu}$ amaçla işletilen konutlara pansiyon, işletmecilere pansiyoncu, konaklayanlara da pansiyoner denmektedir. Turistik bölgelerde şehir konutları yanında köy evleri de pansiyon amaciyla işletilmektedir (Doğanay, 2001: 534-535).

Türkiye'de 2020 yılı sonu itibariyle 135 pansiyon işletmesi yer almaktadır. Bu pansiyonlarda 1.561 oda ve 3.146 yatak kapasitesi vardır (Tablo 8). Esasında bu değer, Türkiye'nin turizm sektörünün büyüklüğü ile mukayese edilirse, çok düşük olduğu dikkati çekmektedir. Türkiye'de teşebbüs eksikliği ve öneminin yeterince anlaşılamaması gibi pek çok etkenin yanı sıra bazı kültürel değerler de pansiyon konaklamasının ve pansiyonculuğun gelişmesini olumsuz yönde etkilemektedir. 
Tablo 8. Türkiye'de Pansiyonların İllere Dağılışı (2020)

\begin{tabular}{|l|r|r|r|l|r|r|r|}
\hline \multicolumn{1}{|c|}{$\begin{array}{c}\text { İlin } \\
\text { Adı }\end{array}$} & $\begin{array}{c}\text { Pansiyon } \\
\text { Sayısı }\end{array}$ & $\begin{array}{c}\text { Oda } \\
\text { Sayısı }\end{array}$ & \multicolumn{1}{c|}{$\begin{array}{c}\text { Yatak } \\
\text { Sayısı }\end{array}$} & $\begin{array}{c}\text { İlin } \\
\text { Adı }\end{array}$ & $\begin{array}{c}\text { Pansiyon } \\
\text { Sayısı }\end{array}$ & $\begin{array}{c}\text { Oda } \\
\text { Sayısı }\end{array}$ & $\begin{array}{c}\text { Yatak } \\
\text { Sayısı }\end{array}$ \\
\hline Amasya & 4 & 57 & 112 & Karabük & 1 & 6 & 12 \\
\hline Antalya & 10 & 163 & 337 & Kars & 3 & 55 & 84 \\
\hline Aydın & 1 & 17 & 34 & Kastamonu & 2 & 24 & 45 \\
\hline Balıkesir & 1 & 16 & 32 & Kayseri & 1 & 15 & 30 \\
\hline Bartın & 1 & 5 & 10 & Kocaeli & 3 & 47 & 88 \\
\hline Bolu & 4 & 33 & 72 & K.Maraş & 1 & 20 & 40 \\
\hline Bursa & 3 & 39 & 78 & Mardin & 1 & 8 & 18 \\
\hline Çanakkale & 7 & 66 & 138 & Muğla & 9 & 128 & 264 \\
\hline Çankırı & 1 & 25 & 50 & Nevşehir & 37 & 327 & 661 \\
\hline Denizli & 1 & 12 & 24 & Ordu & 1 & 24 & 48 \\
\hline Düzce & 2 & 11 & 22 & Sakarya & 1 & 5 & 18 \\
\hline Erzincan & 1 & 6 & 12 & Samsun & 1 & 22 & 44 \\
\hline Eskişehir & 1 & 12 & 24 & Trabzon & 2 & 37 & 85 \\
\hline Giresun & 3 & 20 & 42 & Tunceli & 1 & 18 & 36 \\
\hline Isparta & 2 & 17 & 36 & Şanlıurfa & 1 & 5 & 10 \\
\hline İstanbul & 11 & 139 & 283 & Uşak & 1 & 19 & 38 \\
\hline İzmir & 15 & 153 & 299 & Zonguldak & 1 & 10 & 20 \\
\hline & & & & & $\mathbf{1 3 5}$ & $\mathbf{1 . 5 6 1}$ & $\mathbf{3 . 1 4 6}$ \\
\hline
\end{tabular}

Kaynak: Kültür ve Turizm Bakanlığı, 2020.

Pansiyonların illere dağılışı incelendiğinde, hemen her coğrafi bölgeden toplam 34 ilde pansiyonların bulunduğu ve 47 ilde ise hiç bulunmadığı görülmektedir. Pansiyonların daha çok ülkenin kıyı kesiminde olduğu ayırt edilmektedir. Bununla birlikte en fazla pansiyon Nevşehir ilinde yer almaktadır (Harita 4). Nevşehir'de 37 pansiyonda toplam 327 oda ve 661 yatak kapasitesi mevcuttur. Nevşehir'den sonra İzmir (15), İstanbul (11), Antalya (10), Muğla (9) ve Canakkale (7) illeri suralanmaktadır (Foto 4, Tablo 8). 18 ilde ise yalnızca bir adet pansiyon hizmet vermektedir. Ürgüp-Göreme yöresinde turizm merkezi durumunda olan Nevşehir'de daha çok kısa süreli konaklama yapıldığından pansiyon sayısının fazla olduğu düşünülmektedir. Bu konaklama türünün diğer konaklama türlerine göre daha ucuz olması da bir diğer etkendir.

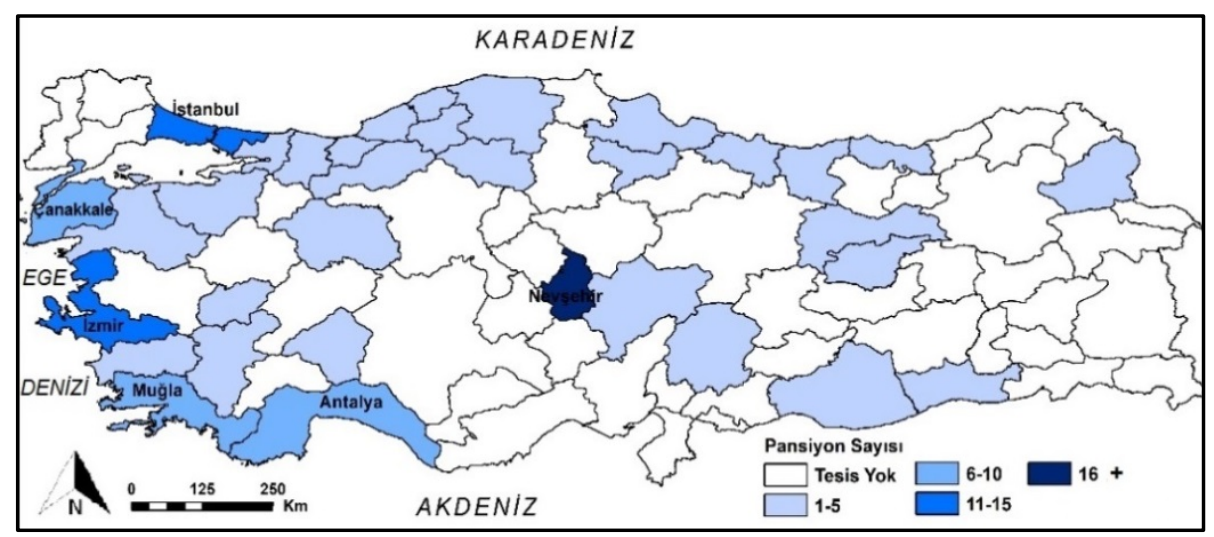

Harita 4. Türkiye'de Pansiyonların İllere Dağılışı (2020) 


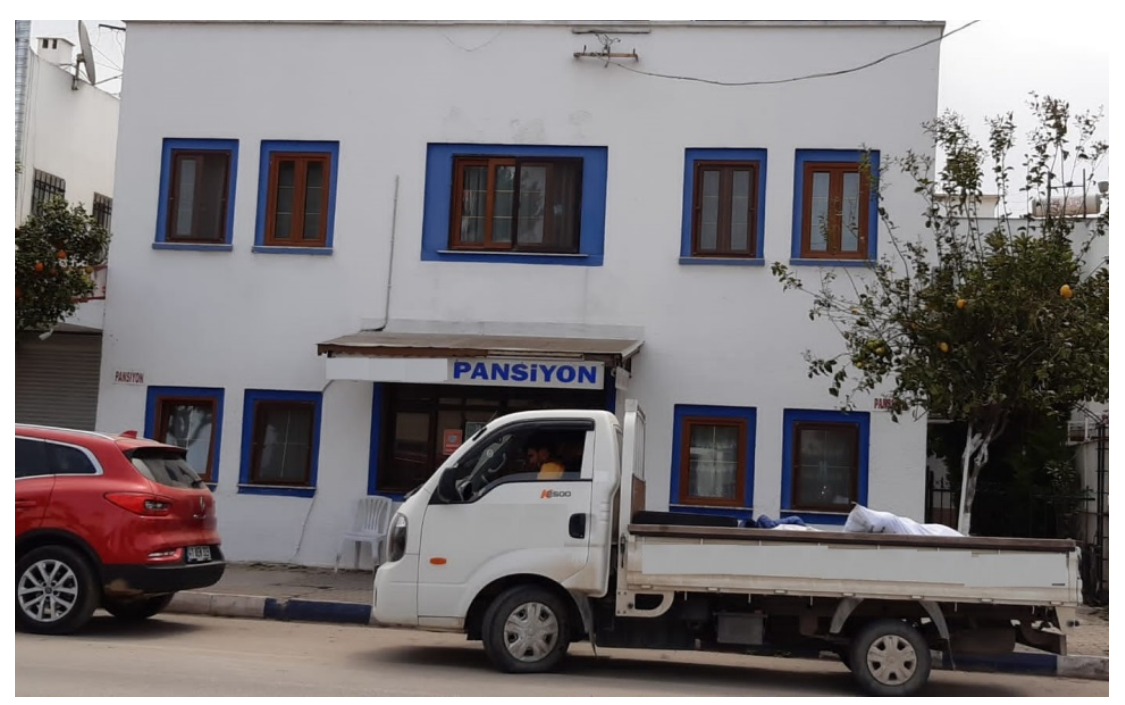

Foto 4. Bodrum'da konaklama hizmeti veren pansiyonlardan biri.

Bütün bu verilere ve açıklamalara göre, Türkiye'de turistik konaklamada pansiyon türünün fazla yaygınlaşmadığı ve bundan yeterince yararlanılmadığı anlaşılmaktadır. $\mathrm{Bu}$ nedenle pansiyonculuğun teşvik edilmesi ve yerel halkın daha fazla katılımının sağlanması gerekmektedir. Konaklama türleri içinde nispeten ucuz olan pansiyon sayısının artması, orta ve alt gelir gruplarının turizm faaliyetlerine katılımını da kolaylaştıracaktır.

\section{Kamping}

Kamping (İng: Camping), kamp yapmak demektir. Terim, kamp yeri anlamında da kullanılır. Kampingler çeşitli amaçlarla ve farklı mekânlarda kurulmaktadır. Sosyal, kültürel ve sportif amaçlarla kamp kurulduğu gibi, bilimsel çalışma, dinlenme, eğlenme ve dış turizme yönelik kamplar da kurulmaktadır (Doğanay, 2001: 532). Kamplar daha çok deniz ve göl kıyıları ile orman kenarı gibi doğal güzelliklere yakın yerlerde veya şehir yerleşmelerine yakın rekreasyon alanlarında yoğunluk kazanmaktadır. Bunun yanında ulaşım güzergâhları üzerinde ve turizm merkezleri yakınlarında da kamp yerleri mevcuttur (Y1ldız, 2011: 36).

Kampingler, ulaşım güzergâhlarında veya doğal güzelliğe sahip alanlarda kurulan, ihtiyaçları müşteriler tarafından karşılanan ve en az 10 üniteye sahip tesisler olarak tanımlanır (Resmi Gazete, 2019: 115). Dolayısıyla kamp alanlarının gelişmesi ve sayı bakımından çoğalması ulaşım imkânlarının gelişmesiyle paralel yürümektedir. Günümüzde ulaşımın gelişmesi, mesafelerin yakınlaşması, güvenliğin sağlanması gibi nedenlerle kamping faaliyetlerinde artışlar meydana gelmektedir. Kamping alanlarındaki konutlar (çadır, bungalov, şale) genellikle seyyar olmakla birlikte bazı kamp alanlarında sabit kamp konutları da bulunmaktadır (Aktaş, 2002: 36).

Kamping alanlarında çevre düzenlemeleri ile gerekli ağaçlandırma, çimlendirme ve aydınlatma sağlanmaktadır. Yeme-içme, eğlenme, dinlenme, okuma, spor vb. faaliyetlerin sağlıklı yapılması için gerekli düzenlemeler yapılmaktadır. Kampçılar için gerekli alan düzenlemeleri ile karavanlar için bakım, onarım ve geceleme ihtiyaçları karşılanır. Kamp alanlarında tuvalet, duş, elektrik, su ve ilk yardım hizmetleri için gerekli tedbirler alınır (Koçhan, 2015: 23).

Türkiye'de 2020 y1lı itibariyle turizm işletmeli 1.125 yatak kapasiteli toplam 6 kamping tesis hizmet vermektedir. Yatırım işletmeli toplam 2.323 yatak kapasiteli 8 
kamping tesisinin yapımı sürmektedir. Kamping tesislerine olan talep sayısındaki artış ile birlikte tesis sayısında da artış gerçekleşmektedir. Bu tesisler Antalya, Çanakkale, Düzce, İstanbul, İzmir ve Muğla'da faaliyet göstermektedir. En fazla yatak kapasitesi 420 yatak ile Muğla ilinde yer almaktadır. Daha sonra 350 yatakla İstanbul, 120 yatakla Çanakkale, 100 yatakla İzmir, 90 yatakla Antalya ve 45 yatakla Düzce sıralanmaktadır (Kültür ve Turizm Bakanlığı, 2020).

\section{Tatil Köyü}

Tatil köyleri, planlı ve mevsimlik yerleşmeler olarak tanımlanır. Tatil yapma, dinlenme, eğlenme, sportif faaliyetler gibi çok yönlü fonksiyonlara sahiptir (Doğanay, 2001: 536). Tatil köyleri planlı yerleşim olduğundan sosyal donatı alanları mevcuttur. Böylece turistler çeşitli ihtiyaçlarını rahatlıkla karşılama imkânı bulmaktadir.

Tatil köyleri doğa ile iç içe rahat bir konaklama hizmeti vermektedir. Tatil köylerinde yöresel değerlerin korunması, çevre düzenlemesinin nitelikli olması, yerleşmenin yatay bir şekilde inşa edilmesi gerekmektedir. Bu tesisler en fazla 3 kattan ve en az 80 odadan meydana gelmelidir (Y1ldı, 2011: 36).

Türkiye'de 2020 yılı itibariyle 55.434 yatak kapasiteli 69 birinci sınıf ve 2.890 yatak kapasiteli 9 ikinci sınıf turizm işletmeli tatil köyü vardır (Tablo 9). Bunlara ilaveten 6.599 yatak kapasiteli 13 birinci sınıf, 7.732 yatak kapasiteli 7 ikinci sınıf, bakanlık işletme belgeli 310 yatak kapasiteli 5 yıldızlı ilk termal tatil köyün inşası da devam etmektedir. Öte yandan ülkenin çeşitli yerlerinde belediye işletme belgeli tatil köyleri de hizmet vermektedir. Konya İsmil, Diyarbakır Çermik Helinamın ve Aksaray Ihlara termal tatil köyleri bunlara örnek olarak verilebilir (Foto 5).

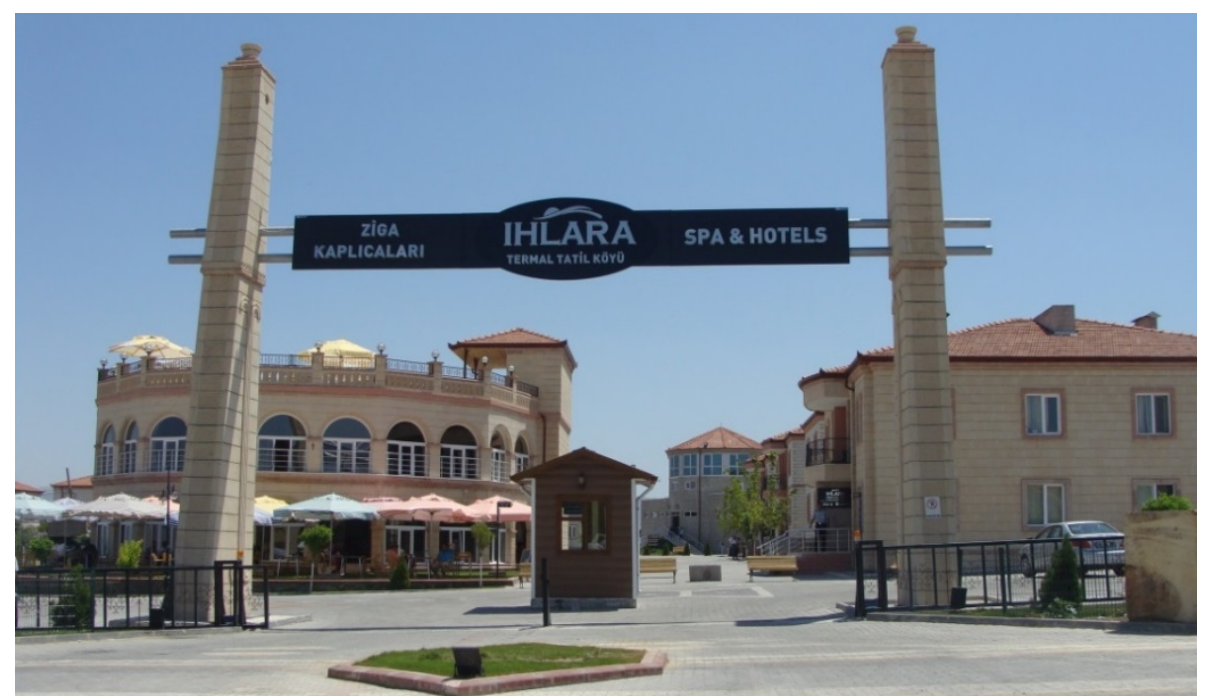

Foto 5. Aksaray ilinin Ziga mevkiinde yer alan Ihlara Termal Tatil Köyü.

Türkiye'de toplamda 78 tatil köyü 26.464 oda ve 58.324 yatak kapasitesiyle hizmet vermektedir (Tablo 9). Tatil köyleri 6 ilde başka bir ifadeyle çok sınırlı sayıdaki ilde dağılış arz etmektedir. Bu iller arasında 43 tesisle Antalya ilk sırada yer almaktadır. İkinci sırada 25 tesisle Muğla ve çok daha az sayıdaki tesislerle İzmir (4), Aydın (3), Balıkesir (2) ve Mersin (1) illeri izlemektedir. Türkiye'de tatil köylerinin Balıkesir ve Mersin illeri arasına karşılık gelen Ege ve Akdeniz kıyı kuşağında yer aldığı 
görülür (Harita 5). Dolayısıyla tatil köylerinin dağılışı, kıyı turizminin gelişim alanlarıyla sınırlı kalmıştır.

Tablo 9. Türkiye'de Tatil Köylerinin İllere Dağılışı (2020)

\begin{tabular}{|l|l|r|r|r|l|r|r|r|r|}
\hline \multicolumn{1}{|c|}{$\begin{array}{c}\text { İlin } \\
\text { Adı }\end{array}$} & Sınıfı & $\begin{array}{r}\text { Tatil } \\
\text { Köyü }\end{array}$ & $\begin{array}{r}\text { Oda } \\
\text { Sayısı }\end{array}$ & $\begin{array}{r}\text { Yatak } \\
\text { Sayısı }\end{array}$ & $\begin{array}{c}\text { İlin } \\
\text { Adı }\end{array}$ & Sınıfı & $\begin{array}{r}\text { Tatil } \\
\text { Köyü }\end{array}$ & $\begin{array}{r}\text { Oda } \\
\text { Sayısı }\end{array}$ & $\begin{array}{r}\text { Yatak } \\
\text { Sayısı }\end{array}$ \\
\hline Antalya & 1 & 42 & 16913 & 37490 & İzmir & 2 & 2 & 182 & 364 \\
\hline Antalya & 2 & 1 & 416 & 964 & Mersin & 1 & 1 & 320 & 640 \\
\hline Aydın & 1 & 3 & 1189 & 2468 & Muğla & 1 & 21 & 5860 & 12994 \\
\hline Balıkesir & 2 & 2 & 176 & 368 & Muğla & 2 & 4 & 595 & 1194 \\
\hline İzmir & 1 & 2 & 813 & 1842 & \multicolumn{2}{|c|}{ Toplam } & $\mathbf{7 8}$ & $\mathbf{2 6 . 4 6 4}$ & $\mathbf{5 8 . 3 2 4}$ \\
\hline
\end{tabular}

Kaynak: Kültür ve Turizm Bakanlığı, 2020.

\section{Hosteller}

Hosteller, daha çok gençlik turizmine konaklama ve yeme-içme hizmeti vermektedir (Resmi Gazete, 2005: 4532). Düşük bütçe ile seyahat eden sırt çantalı gezginler ve öğrenciler için ucuz konaklama imkânı sunmaktadır. Hosteller, en az on odalı olmalıdır (Koçhan, 2015: 27). Eğlenme, duş, çamaşır, telefon, internet, ilk yardım hizmetlerin sağlıklı verilmesi için gerekli tedbirlerin alındığ

Yaya veya bisikletle seyahat eden kişi ve grupların konakladığı tesislere de hostel adı verilir. Han ve öğrenci yurdu anlamlarına da gelir. Öğretmen denetiminde çeşitli amaçlarla seyahat eden öğrencilerin konakladığ 1 tesisler yurt olarak tanımlanırken, diğer grupların konakladığı tesisler ise, han olarak tanımlanmaktadır. Her ikisine birden hostel denir. Öğrenci yurtları bu konaklama türü içinde kabul edilmediğinden Türkiye'de hostel mevcut değildir (Doğanay, 2001: 543). Aynı şekilde Türkiye'de 2020 yılı itibariyle Turizm Bakanlığı konaklama türleri sınıflandırmasına göre de hostel bulunmamaktadir.

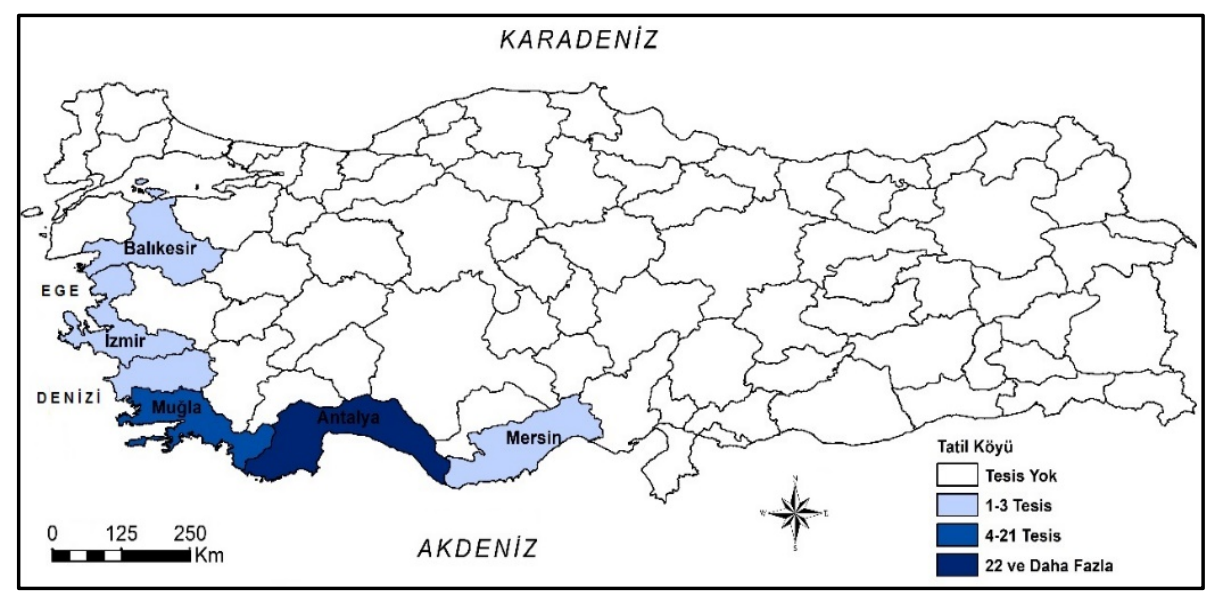

Harita 5. Türkiye'de Tatil Köylerinin İllere Dağılışı (2020) 


\section{Dağ Evi / Oberj}

Dağ oteli olarak da isimlendirilir. Bunlar, kırsal turizm tesisleri sınıfında yer almaktadır. Doğal güzellikleri olan sahalarda, kış sporu merkezlerinde, ormanlık alanlar ile vadilerde inşa edilmektedir. Tesislerde hem spor etkinlikleri yapılmakta hem de doğal güzellikler izlenmektedir (Doğanay, 2001: 541). Oberjler, genellikle şehir dışında, doğal güzelliklere sahip, kış ve dağ sporlarının yapılabildiği ve turistik yollarla entegre sahalarda kurulmaktadır (Barutçugil, 1989: 54). Dağ evi en az bir yıldızlı, odalar, ranza sistemi olmadan en fazla altı kişilik olmalıdır (Resmi Gazete, 2005: 4542).

Türkiye'de 2020 itibariyle 970 yatak kapasiteli toplam 3 oberj tesisi bulunmaktadır. Yine 359 yatak kapasiteli toplam 4 adet turizm işletmeli dağ evi tesisi mevcuttur. 312 yatak kapasiteli 5 turizm yatırım tesisinin inşası ise devam etmektedir. Bolu'da 2, Ankara'da 1 tesis faaliyet gösterirken, Bolu, Kayseri, Rize ve Trabzon'da birer tesis faaliyet göstermektedir. Dağ evi / oberjler yayla turizmi ve kış turizminin geliştiği illere dağılmıştır.

\section{Diğer Konaklama Tesisleri}

Bu grupta B tipi tatil sitesi, butik tatil villası, çiftlik evi/köy evi, golf tesisi, kırsal turizm tesisi, özel tesis, turizm kompleksi ve yayla evi yer almaktadır. Türkiye'de toplam 439 diğer konaklama tesisinde 16.800 oda ve 35.066 yatak kapasitesi bulunmaktadır. B tipi tatil sitesi Muğla ve İstanbul'da birer olmak üzere 2 adettir. $\mathrm{Bu}$ tesislerde toplam 42 oda ve 236 yatak kapasitesi mevcuttur. Butik tatil villası, 70 oda ve 140 yatak kapasitesi ile İzmir'de hizmet vermektedir. 12 çiftlik evi/ köy evinde toplam 112 oda ve 225 yatak kapasitesi vardır. İzmir'de 3, Düzce'de 2, Denizli, Edirne, Muğla, Kahramanmaraş, Nevşehir, Ordu ve Tunceli'de birer tesis mevcuttur (Tablo 10).

Türkiye'de golf tesisi 3 adet olup, 531 oda ve 1.348 yatak kapasitesi ile sadece Antalya'da hizmet vermektedir. Toplam 4 adet kırsal turizm tesisinde 61 oda ve 120 yatak bulunmaktadır. Bu tesisler Çanakkale, İzmir, Kahramanmaraş ve Sinop'ta yer almaktadır. 411 özel tesiste 12.911 oda ve 26.465 yatak kapasitesi vardır. En fazla özel tesis İstanbul'dadır. Bu ilde 137 tesis hizmet vermektedir. Daha sonra sırasıyla Nevşehir, İzmir, Antalya, Karabük, Muğla, Çanakkale ve Balıkesir illeri takip etmektedir.

Türkiye'de mevcut olan toplam 4 turizm kompleksinden 3'ü Antalya'da ve 1'i de İstanbul'da faaliyet göstermektedir. Bu tesislerde toplam 3.043 oda ve 6.442 yatak bulunmaktadır. Ayrıca 30 oda ve 90 yatak kapasiteli toplam 2 yayla evi vardır ve bunlar Hatay ve Ordu illerinde yer almaktadır (Harita 6).

Gezi ve sportif amaçlarla kullanılan motorlu teknelere yat, teknelerin barındığı ve temel ihtiyaçlarını karşıladığı yerlere de Marina ya da Yat Limanı adı verilmektedir. Yat limanları turistik konaklama yönetmeliğine göre diğer tesisler sınıfında yer almaktadır. Yatlar, geceleme yapıldığından turistik konaklama tesisi olarak kabul edilmektedir (Doğanay, 2001: 539). Türkiye'de İstanbul, Ege ve Akdeniz sahilleri yat limanlarının yoğunlaştı̆̆ı sahalar olarak göze çarpmaktadır. Türkiye'de ilk yat limanları Muğla (Bodrum, Marmaris), Aydın (Kuşadası) ve Antalya (Kaleiçi, Kemer) illerinde faaliyete girmiştir. 
Tablo 10. Diğer Konaklama Tesislerinin İllere Dağılışı (2020)

\begin{tabular}{|c|c|c|c|c|c|c|c|}
\hline $\begin{array}{l}\text { İlin } \\
\text { Adı }\end{array}$ & $\begin{array}{l}\text { Tesis } \\
\text { Sayısı }\end{array}$ & $\begin{array}{c}\text { Oda } \\
\text { Sayısı }\end{array}$ & $\begin{array}{l}\text { Yatak } \\
\text { Sayısı }\end{array}$ & $\begin{array}{l}\text { İlin } \\
\text { Adı }\end{array}$ & $\begin{array}{c}\text { Tesis } \\
\text { Sayısı } \\
\end{array}$ & $\begin{array}{c}\text { Oda } \\
\text { Sayısı } \\
\end{array}$ & $\begin{array}{l}\text { Yatak } \\
\text { Sayısı } \\
\end{array}$ \\
\hline \multicolumn{4}{|c|}{ Motel Sayısı } & \multicolumn{4}{|c|}{ Çiftlik/Köy Evi Sayısı } \\
\hline Adana & 1 & 75 & 150 & Denizli & 1 & 15 & 30 \\
\hline Mersin & 1 & 65 & 134 & Düzce & 2 & 33 & 66 \\
\hline Ankara & 1 & 20 & 40 & Edirne & 1 & 10 & 20 \\
\hline Denizli & 1 & 15 & 30 & İzmir & 3 & 21 & 44 \\
\hline Elazı̆̆ & 1 & 39 & 81 & K.Maraş & 1 & 10 & 20 \\
\hline Toplam & 5 & 214 & 435 & Muğla & 1 & 5 & 10 \\
\hline \multicolumn{4}{|c|}{ Dağevi/Oberj Sayısı } & Nevşehir & 1 & 5 & 15 \\
\hline Bolu & 3 & 473 & 1024 & Ordu & 1 & 8 & 10 \\
\hline Ankara & 1 & 30 & 66 & Tunceli & 1 & 5 & \\
\hline Kayseri & 1 & 31 & 69 & Toplam & 12 & 112 & 225 \\
\hline Rize & 1 & 9 & 18 & & & & \\
\hline Trabzon & 1 & 51 & 152 & \multicolumn{4}{|c|}{ Kırsal Turizm Sayısı } \\
\hline Toplam & 7 & 594 & 1329 & Çanakkale & 1 & 19 & 44 \\
\hline \multicolumn{4}{|c|}{ Kamping Sayısı } & İzmir & 1 & 12 & 24 \\
\hline Muğla & 1 & 140 & 420 & K.Maraş & 1 & 15 & 34 \\
\hline İstanbul & 1 & 116 & 350 & Sinop & 1 & 15 & 18 \\
\hline İzmir & 1 & 50 & 100 & Toplam & 4 & 61 & 120 \\
\hline Çanakkale & 1 & 40 & 120 & \multicolumn{4}{|c|}{ Yayla Evi Sayısı } \\
\hline Antalya & 1 & 30 & 90 & Hatay & 1 & 15 & 30 \\
\hline Düzce & 1 & 15 & 45 & Ordu & 1 & 15 & 60 \\
\hline Toplam & 6 & 391 & 1125 & Toplam & 2 & 30 & 90 \\
\hline \multicolumn{4}{|c|}{ Turizm Kompleksi Sayısı } & \multicolumn{4}{|c|}{ Golf Tesisi Sayısı } \\
\hline Antalya & 3 & 2203 & 4678 & Antalya & 3 & 531 & 1348 \\
\hline İstanbul & 1 & 840 & 1764 & Toplam & 3 & 531 & 1348 \\
\hline Toplam & 4 & 3043 & 6442 & & & & \\
\hline
\end{tabular}

Kaynak: Kültür ve Turizm Bakanlığı, 2020.

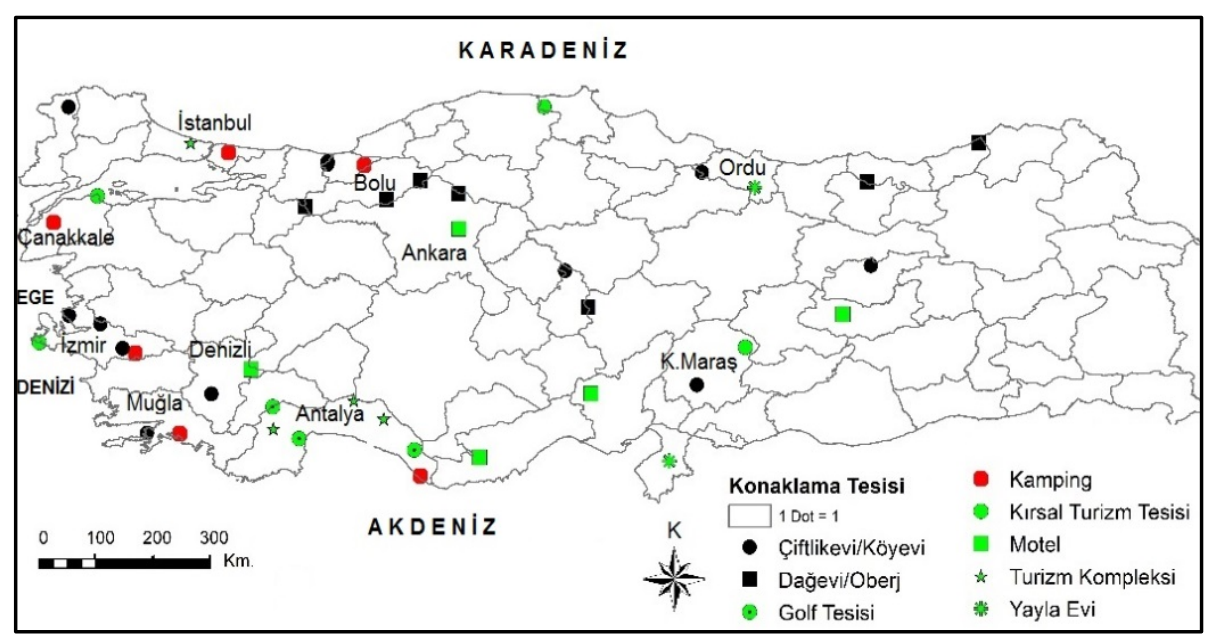

Harita 6. Türkiye'de Diğer Turistik Konaklama Tesislerinin İllere Dağılışı (2020) 


\section{Belediye İşletme Belgeli Konaklama Tesisleri}

Belediye işletme belgeli konaklama tesisleri de türlerine göre sınıflandırılmaktadır. Fakat sınıflandırmada genel bir karmaşa olmaktadır. Çünkü tesisler, hangi türde işletilirse işletilsin belediye işletme belgeli tesis şeklinde kayıtlara geçmektedir. Türkiye'deki tüm turistik konaklama tesislerinin bakanlığa bağlanmasıyla birlikte daha sağlıklı bir sınıflandırma ve dağılımın ortaya çıkması beklenmektedir.

Belediye işletme belgeli konaklama tesislerinin işletme ve denetimleri yerel yönetimler tarafından yapılmaktadır. Bu işletmeler, iş yeri açma ve çalıştırma ruhsatına ilişkin esaslara göre birinci, ikinci ve üçüncü sınıf tesis olarak sınıflandırılmaktadır. Bu işletmelerin turizm işletme belgesi bulunmamaktadır. Oda fiyatları da çeşitli kriterlere göre belediyeler tarafından belirlenmektedir (MEB, 2006: 8). Belediye işletme belgeli konaklama tesislerinin hizmet kalitesi ve standartları turizm işletme belgeli tesislere göre daha düşük düzeydedir.

Türkiye'de 2020 yılı itibariyle farklı türlerde toplam 8.609 belediye işletme belgeli tesis hizmet vermektedir (Tablo 11, Grafik 3). Bu tesislerin \%56,9'unu oteller, \% 29,8'ini pansiyonlar ve \%8,5'ini kamu misafirhaneleri teşkil etmektedir. Geriye kalan \% 4,8 tesisi ise motel, kamping, kaplıca ve tatil köyleri meydana getirmektedir. Türkiye'nin her iline dağılan kamu misafirhaneleri (üniversite konukevi, öğretmenevi, polisevi, orduevi vb.) genellikle kurum ve kuruluşun adıyla anılmakta, 736 tesis ve 41.408 adet yatakla konaklama hizmeti vermektedir.

Tablo 11: Türkiye'de Belediye İşletme Belgeli Tesislerin Türlerine Dağılımı (2020)

\begin{tabular}{|l|r|r|r|}
\hline Tesis Türü & Tesis Sayısı & \multicolumn{1}{c|}{ Yatak Sayısı } & \multicolumn{1}{c|}{ Oran (\%) } \\
\hline Otel & 4.902 & 397.408 & 56,9 \\
\hline Pansiyon & 2.565 & 86.821 & 29,8 \\
\hline Kamu Misafirhanesi & 736 & 41.408 & 8,5 \\
\hline Motel & 204 & 8.569 & 2,4 \\
\hline Kamping & 66 & 5.837 & 0,8 \\
\hline Kaplıca & 90 & 19.342 & 1,1 \\
\hline Tatil Köyü & 46 & 16.297 & 0,5 \\
\hline Toplam & $\mathbf{8 . 6 0 9}$ & $\mathbf{5 7 5 . 6 8 2}$ & $\mathbf{1 0 0}$ \\
\hline
\end{tabular}

Kaynak: Kültür ve Turizm Bakanlığı, 2020.

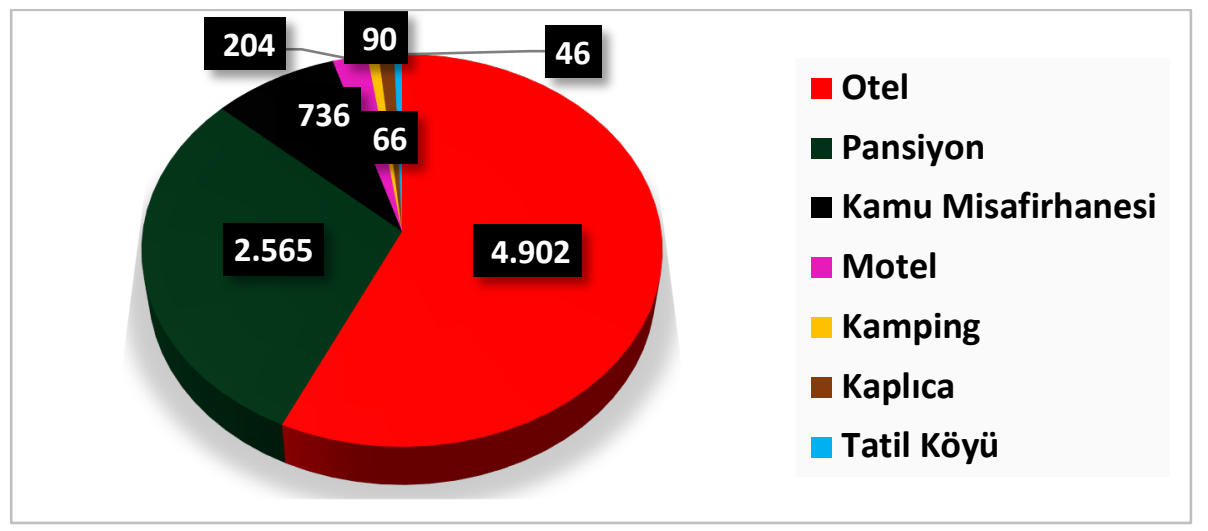

Grafik 3. Türkiye'de Belediye İşletme Belgeli Tesislerin Türlere Dağılımı (2020) 
Türkiye'de 2020 y1lı itibariyle belediye işletme belgeli 8.609 konaklama tesisi toplam 253.268 oda ve 575.682 yatak kapasitesiyle hizmet vermektedir (Tablo 12). Oysa 2000 yılında Türkiye'yi de belediye işletme belgeli toplam 7.836 konaklama tesisi ve 344.886 yatak kapasitesi vardı (https://yigm.ktb.gov.tr). 20 y1llık dönemde tesis sayısının nispeten daha az artmasına karşılık yatak kapasitesinde 230.429, başka bir ifadeyle yaklaşık \%67 oranında büyük bir artış meydana gelmiştir.

Tablo 12. Belediye İşletme Belgeli Konaklama Tesislerinin İllere Dağılışı (2020)

\begin{tabular}{|c|c|c|c|c|c|c|c|}
\hline $\begin{array}{l}\text { İlin } \\
\text { Adı }\end{array}$ & $\begin{array}{c}\text { Tesis } \\
\text { Sayısı }\end{array}$ & $\begin{array}{c}\text { Oda } \\
\text { Sayısı }\end{array}$ & $\begin{array}{l}\text { Yatak } \\
\text { Sayısı }\end{array}$ & $\begin{array}{l}\text { İl } \\
\text { Adı }\end{array}$ & $\begin{array}{c}\text { Tesis } \\
\text { Sayısı }\end{array}$ & $\begin{array}{c}\text { Oda } \\
\text { Sayısı }\end{array}$ & $\begin{array}{l}\text { Yatak } \\
\text { Sayısı }\end{array}$ \\
\hline Adana & 74 & 2017 & 3699 & K.Maraș & 22 & 469 & 910 \\
\hline Adiyaman & 23 & 748 & 1375 & Karabük & 98 & 1124 & 2571 \\
\hline A.Karahisar & 102 & 5108 & 13748 & Karaman & 4 & 125 & 202 \\
\hline Aksaray & 14 & 513 & 1086 & Kars & 23 & 610 & 1208 \\
\hline Amasya & 65 & 900 & 2013 & Kastamonu & 79 & 1641 & 3728 \\
\hline Ankara & 60 & 2323 & 4610 & Kayseri & 34 & 1257 & 2728 \\
\hline Antalya & 1028 & 53116 & 136644 & Kilis & 6 & 213 & 446 \\
\hline Ardahan & 16 & 301 & 628 & Kocaeli & 114 & 2664 & 6551 \\
\hline Artvin & 87 & 1809 & 3651 & Konya & 122 & 3270 & 6636 \\
\hline Aydın & 127 & 5081 & 12053 & Kütahya & 35 & 1386 & 4079 \\
\hline Ağrn & 10 & 382 & 674 & Kırklareli & 25 & 664 & 1307 \\
\hline Balıkesir & 472 & 11552 & 29456 & Kırıkkale & 10 & 290 & 471 \\
\hline Bartın & 251 & 2128 & 5290 & Kırșehir & 9 & 293 & 583 \\
\hline Batman & 14 & 482 & 993 & Malatya & 25 & 927 & 1778 \\
\hline Bayburt & 4 & 73 & 122 & Manisa & 74 & 2021 & 4698 \\
\hline Bilecik & 18 & 379 & 791 & Mardin & 47 & 1467 & 3138 \\
\hline Bingöl & 5 & 144 & 240 & Mersin & 452 & 10215 & 25542 \\
\hline Bitlis & 18 & 612 & 1213 & Muğla & 901 & 28642 & 64861 \\
\hline Bolu & 98 & 1981 & 4104 & Muș & 26 & 607 & 1178 \\
\hline Burdur & 50 & 929 & 1987 & Nevşehir & 324 & 5827 & 13732 \\
\hline Bursa & 181 & 5042 & 11299 & Niğde & 23 & 917 & 2133 \\
\hline Çanakkale & 342 & 6678 & 15723 & Ordu & 32 & 597 & 1267 \\
\hline Çankırı & 18 & 438 & 955 & Osmaniye & 14 & 358 & 702 \\
\hline Çorum & 41 & 991 & 1944 & Rize & 36 & 1197 & 2597 \\
\hline Denizli & 13 & 391 & 806 & Sakarya & 71 & 1539 & 3263 \\
\hline Diyarbakır & 21 & 560 & 1076 & Samsun & 24 & 410 & 862 \\
\hline Düzce & 67 & 1664 & 3711 & Siirt & 7 & 298 & 570 \\
\hline Edirne & 97 & 2586 & 5972 & Sinop & 76 & 1377 & 3673 \\
\hline Elazığ & 18 & 465 & 898 & Sivas & 54 & 1764 & 3557 \\
\hline Erzincan & 31 & 770 & 1543 & Şanliurfa & 65 & 1904 & 4269 \\
\hline Erzurum & 101 & 2701 & 5388 & Şırnak & 9 & 258 & 695 \\
\hline Eskișehir & 28 & 994 & 2106 & Tekirdağ & 52 & 1284 & 2576 \\
\hline Gaziantep & 16 & 554 & 1074 & Tokat & 52 & 1169 & 2656 \\
\hline Giresun & 45 & 795 & 1746 & Trabzon & 45 & 1208 & 2677 \\
\hline Gümüșhane & 14 & 266 & 554 & Tunceli & 1 & 7 & 14 \\
\hline Hakkâri & 13 & 339 & 737 & Uşak & 11 & 245 & 435 \\
\hline Hatay & 144 & 3613 & 8534 & Van & 48 & 1766 & 4012 \\
\hline Isparta & 43 & 1036 & 2258 & Yalova & 94 & 2524 & 6243 \\
\hline Iğdır & 11 & 426 & 829 & Yozgat & 44 & 980 & 1936 \\
\hline İstanbul & 1430 & 43231 & 81898 & Zonguldak & 27 & 727 & 1440 \\
\hline İzmir & 184 & 4909 & 10330 & Toplam & 8.609 & 253.268 & 575.682 \\
\hline
\end{tabular}

Kaynak: Kültür ve Turizm Bakanlığı, 2020.

Belediye işletme belgeli tesisler bakımından İstanbul 1.430 tesisle ilk sırada yer almaktadır. İkinci sırada 1.028 tesisle Antalya gelirken, Muğla 901, Balıkesir 462, Mersin 452, Çanakkale 342, Nevşehir 324 tesisle ilk 7 sırayı paylaşmaktadır. Buna karşılık belediye işletme belgeli en az tesise sahip olan il de 1 tesisle Tunceli'dir. Bunu 4 tesisle Bayburt ve Karaman takip etmektedir. Bingöl 5, Siirt 7, Kırşehir ve Şırnak 9 tesisle en az tesise sahip olan illerdendir (Harita 7). Tesis sayılarının illere dağılışında, ilin konumu, ulaşım durumu, nüfus büyüklüğü, ekonomik yapısı ve özellikle de nüfus ve turistik hareket yoğunluğunun rol oynadığı ayırt edilmektedir.

Belediye işletme belgeli tesislerin dağılış haritası incelendiğinde, bakanlık işletme belgeli tesislere göre ülke geneline daha fazla yayıldığı görülmektedir (Harita 7). 
Batı Karadeniz, İç Anadolu (Ankara ve Nevşehir hariç), Doğu Anadolu ve Güneydoğu Anadolu bölgelerinde belediye işletme belgeli tesislerin sayısı bakanlık işletme belgeli tesislere göre çok daha fazladır. Bu yörelerde küçük ölçekli işletmeler daha yaygın olduğundan belediye işletme belgeli tesis sayısı da fazladır. Ancak belediye işletme belgeli tesisler, bakanlık işletme belgeli konaklama tesislerinde olduğu gibi İstanbul, Ege ve Akdeniz kıyıları ile Ürgüp - Göreme yöresinde de yoğunluk kazandığı dikkati çekmektedir. Şüphesiz bu durumda turizm faaliyetleriyle yakından ilgilidir.

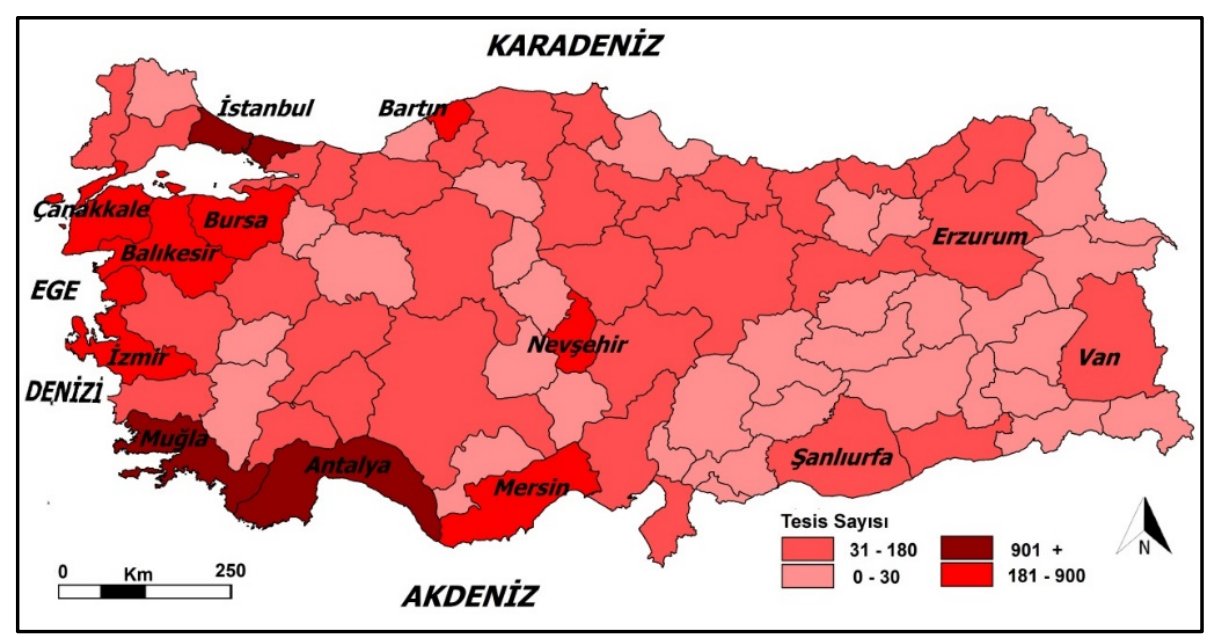

Harita 7. Belediye İşletme Belgeli Konaklama Tesislerinin İllere Dağılışı (2020)

\section{Sonuç Ve Öneriler}

Günümüzde yoğun ve stresli şehir ortamından ya da tekdüze günlük yaşamdan uzaklaşıp farklı bir mekânda zaman geçirmek önemli bir ihtiyaç haline gelmiştir. Bu ihtiyaç, çoğunlukla turizm faaliyetleri kapsamında hizmet veren turistik konaklama tesislerinde giderilmektedir. Turistler, bu tesislerde başta geceleme olmak üzere dinlenme, eğlenme, yeme-içme, alışveriş, spor yapma vb. birçok ihtiyacını karşılamaktadır. Bütün bunların sonuncunda bacasız sanayi de denilen büyük bir ekonomik sektör ortaya çıkmaktadır.

Çoğaltıcı bir özelliğe sahip turizm sektörünün çok çeşitli etkileri olmaktadır. Bunlardan biri de ekonomi alanında görülmektedir. Ülke ekonomisi içindeki payı her geçen yıl artan bu sektör, dış ticaret açığının kapatılmasında önemli bir role sahiptir. Nitekim son yıllarda turizmin ihracat içindeki payı \%20'nin üzerine çıkmıştır. Aynı zamanda turizm sektörü ülke ekonomisi için önemli bir istihdam kaynağını ve tanıtım alanını teşkil etmektedir.

Turistik konaklama tesisleri, ticari işletme olduğundan birbirinden farklı istek ve beklentilere sahip müşterileri memnun etmek için ürün yelpazelerini geniş tutma eğilimindedir. Böylelikle konaklama tesislerinin hizmet kapasitesine göre türü ve büyüklüğü şekillenmektedir. Konaklama tesisleri daha çok konfor düzeyi ve yatak kapasitesine göre sınıflandırılmaktadır. Türkiye'de konaklama tesisleri, bakanlık işletme belgeli ve belediye işletme belgeli olarak iki ana sınıfta ele alınmaktadır. Bakanlık işletme belgeli konaklama tesisleri kendi içinde türlere ayrılırken, belediye işletme belgeli tesislerde de türlere göre bir sınıflandırma mevcuttur. Bu durum

Turkish Academic Research Review - Türk Akademik Araştırmalar Dergisi 
sınıflandırma ve yetki karmaşasına neden olmaktadır. Önümüzdeki dönemde tüm turistik konaklama işletmelerinin bakanlık işletme belgesine sahip olacağı, böylece konaklama tesisleri tek merkezden belgelendirilip denetleneceği ve bu konuda yaşanan karmaşanın giderileceği beklenmektedir.

Turistik konaklama tesislerinin sınıflandırılmasındaki bir diğer sorun da tür sayısının fazla olmasıdır. İşletmeler türlerine göre daha az sayıda ve sade bir sınıflandırmaya tabi tutulmalıdır. Çünkü oteller, sınıflandırılırken yıldızlarına göre, termal veya butik olup olmamalarına göre çok sayıda alt sınıfa ayrılmıştır. Diğer bazı türlerde de benzer ayrımlar söz konusu olmaktadır.

Otel, motel ve pansiyon geleneksel konaklama tesisleri olarak kabul edilmektedir. Bunların dışında tatil köyü, kamping, hostel, oberj, tatil sitesi, tatil villası, çiftlik evi/köy evi, golf tesisi, kırsal turizm tesisi, özel tesis, turizm kompleksi ve yayla evi diğer konaklama tesisleri olarak sınıflandırılmaktadır. Turistik konaklama içerisinde otellerin ayrı bir yeri vardır. Hem yaygın olması hem de çeşitli konseptlerde ve türlerde hizmet vermesi bakımından en fazla kullanılan turistik konaklama tesisleridir. Otel türleri içinde 5 yıldızlı otellerin de farklı bir konumu vardır. Bir otelin 5 yıldızlı olması için çok sayıda kriteri taşıması gerekmektedir. Bu nedenle her ilimizde 5 yıldızlı otel bulunmamaktadır.

Türkiye'de turistik konaklama tesislerinin gelişimi 1980 'den sonra hız kazanmıştır. 1990'a gelindiğinde turistik konaklama sayısı 3102 ile 1980'e göre 7 kat artmıştır. 1981'de çıkarılan Turizm Teşvik Kanunu'nun tesis sayısının artmasında büyük etkisi olmuştur. Bu kanun özellikle kıyı turizmini desteklediğinden Ege ve Akdeniz’e kıyısı olan illerimizde turistik konaklamanın gelişimi oldukça hızlanmıştır. Bugün turizm işletme belgeli 4218 tesis, 487.376 oda ve 1.020 .985 yatak kapasitesine ulaşılmıştır.

Turizm işletme belgeli konaklama tesislerinin illere dağılışı incelendiğinde, Antalya 807 tesisle açık ara ilk sırada gelmektedir. Daha sonra sırasıyla İstanbul 644, Muğla 412, İzmir 222, Ankara 182, Nevşehir 110, Balıkesir 95 ve Aydın 92 tesisle takip etmektedir. Bakanlık işletme belgeli en az tesis ise Kilis'te olup yalnızca 1 tesis mevcuttur. Diğer illerden Bayburt ve Siirt'te 2'şer, Bingöl ve Iğdır'da 3'er tesis hizmet vermektedir.

Türkiye'de konaklama tesislerinin dağılış düzeninde, özellikle batı, güneybatı ve güney Anadolu kıyılarında konumlanan illerde daha fazla yoğunlaşma eğilimi ayırt edilmektedir. Bu bağlamda Antalya, Muğla, İzmir ve Aydın illeri ilk sıralarda yer almaktadır. Gerçekten doğal ve beşeri ortam şartlarının elverişli olması, buralarda turizm faaliyetlerinin öne çıkmasına yol açmaktadır. Öte yandan İç Anadolu'da bulunan Nevşehir ilinin sıralamada önde olmasında ise, hiç şüphesiz Ürgüp-Göreme yöresinde dünyanın en özgün yer şekillerinden olan peribacalarının doğal ve kültürel çekiciliğinin belirgin etkisi söz konusudur. Dolayısıyla doğal ve beşeri turistik çekiciliklerin önemi ve dağılışı ile konaklama tesislerinin sayısı, türü ve dağılışı arasında çok yakın ilişkiler gözlenmektedir. Bu durum, entegre turizm planlama çalışmalarında bölgesel karakterin önemini ortaya koymaktadır.

Ayrıca yoğun bir istihdam sağlayan turistik konaklama tesislerinin, alternatif turizm türleriyle birlikte Türkiye'nin iç bölgelerinde bulunan illerinde de teşvik edilerek yaygınlık kazanmasına önem verilmelidir. Böylece iller arasında gelişmişlik farkının azaltılmasında turizm sektöründen daha fazla yararlanılmalıdır. 


\section{Kaynakça}

Aktaş, A. (2002). Turizm İşletmeciliği ve Yönetimi. (2. Basım), Antalya: Azim Matbaas1.

Akıncı, Z. (2010). Konaklama İşletmelerinde Kriz Yönetimi: Alanya Bölgesindeki Konaklama Issletmelerinde Kriz Sürecinde Karşılaşılan Sorunların Tespit Ve Çözümüne Yönelik Bir Araştırma, Yayınlanmamış Doktora Tezi, Süleyman Demirel Üniversitesi, Isparta.

Akıncı, Z. (2011). Otel İşletmeciliği. Ankara: Nobel Yayınevi.

Akova, İ. (2008). Turizm Araştırmaları, Istanbul: Çantay Kitabevi.

Akova, İ. (2019). Turizm Coğrafyası, İçinde: Beşeri ve Ekonomik Coğrafya (Editör: M. Doğan, Ö. Sertkaya Doğan), Ankara: Pegem Akademi, s.377-422.

Alaeddinoğlu, F. Toroğlu, E. Elibüyük, M. (2006). Türkiye’de Bölgesel Farklılıklara Göre Konaklama Tesislerinin Gelişimi ve Değişimi, IV. Ulusal Coğrafya Sempozyuтu, Ankara Üniversitesi 25-26 Mayıs 2006. Ankara. Ss:145-152.

Azaltun, M. ve Kaya, E. (2010). Konaklama İşletmelerinde Muhasebe Uygulamaları. (3. Basım), Ankara: Detay Yayıncılık.

Baykal, F. (2019). Türkiye Turizm Coğrafyası, İçinde: Türkiye Beşeri ve İktisadi Coğrafyası (Editör: N. Taşlıgil, G. Sahin), Ankara: Nobel Yayınevi, s.349416.

Barutçugil S. İ. (1989). Turizm İşletmeciliği. (3. Basım), İstanbul: Beta Basım.

Dilber, İ. (2007). Turizm Sektörünün Türkiye Ekonomisi Üzerindeki Etkisinin Girdi Çıktı Tablosu Yardımıyla Değerlendirilmesi, Manisa: Celal Bayar Üniversitesi Yönetim ve Ekonomi Dergisi, 14(2): 205-220.

Dinçer, M. ve Dinçer, F. (1989). Türkiye’de Konaklama Sektörünün Gelișimi ve Başlıca Sorunları Üzerine Bir Araştırma, Istanbul: Istanbul Üniversitesi İktisat Fakültesi Mecmuası, 47 (1-4): 45-57.

Doğanay, H. (2001). Türkiye Turizm Coğrafyası. Konya: Çizgi Kitabevi.

Doğaner, S. (2001). Türkiye Turizm Coğrafyası. Istanbul: Çantay Kitabevi.

Emekli, G. (2006). Coğrafya, Kültür ve Turizm: Kültürel Turizm, İzmir: Ege Coğrafya Dergisi, 15: 51-59.

https://yigm.ktb.gov.tr/Eklenti/68203,08122020-tarihi-itibariyla-bakanlikbelgelikonaklama-t-.xls?0 (Erişim Tarihi 17.12.2020).

https://www.tursab.org.tr/istatistikler/turistik-tesis-isletmeler/ (Erişim Tarihi 21.12.2020).

https://yigm.ktb.gov.tr/TR-201137/belediye-belgeli-tesis-istatistikleri.html (Erişim Tarihi: 17. 12. 2020).

Koçhan, M. (2015). Risk Ve Kriz Dönemlerinde Otel İşletmelerinin Yönetimine Yönelik Bir Araştırma Otel Işsletmelerinde Risk Ve Kriz Yönetimi, Yayınlanmamış Yüksek Lisans Tezi, Düzce Üniversitesi, Düzce.

Kozak, N. Kozak, M.A. Kozak, M. (2011). Genel Turizm Ilkeler- Kavramlar. Ankara: Detay Yayıncılık.

MEB - Milli Eğitim Bakanlığı. (2006). Konaklama ve Seyahat İşletmeleri, Ankara, MEGEP (Mesleki Ĕgitim ve Öğretim Sisteminin Güçlendirilmesi Projesi).

Turkish Academic Research Review - Türk Akademik Araştırmalar Dergisi 
Okuyucu, A. ve Akgiș, Ö. (2016). Türkiye'de Konaklama Sektörünün Yapısal ve Mekânsal Değişimi: 1990-2013, Ankara: Türkiye Sosyal Araştırmalar Dergisi, 20(1):249-269.

Özgüç, N. (1977). Sayfiye Yerleşmeleri: Geliş̧me ve Başlıca Özellikleri, İstanbul: İstanbul Üniversitesi Coğrafya Enstitüsü Dergisi, 22:142-162.

Özgüç, N. (2007). Turizm Coğrafyası (Özellikler ve Bölgeler). İstanbul: Çantay Kitabevi.

Resmi Gazete. (2005). Turizm Tesislerinin Belgelendirilmesine ve Niteliklerine İlişkin Yönetmelik, Ankara: 25852: 4519-4552.

Resmi Gazete. (2019). Turizm Tesislerinin Niteliklerine İlişkin Yönetmelik, Ankara: 30791: 92-120.

TÜROFED. (2008). Konaklamanin Seyahat Pazarındaki Yeri, Ekonomiye Katklları ve Turizm-Endüstri İlişkileri. İstanbul: Özgün Ofset (www.turofed.org.tr).

Usta, Ö. (2001). Genel Turizm. İzmir: Anadolu Matbaası.

Yıldız, Ş. (2011). Beş Yıldızlı Otel İşletmelerinin Örgüt Yapılarının MekanikOrganik Örgüt Yapısı Bağlaminda Incelenmesi, Tezsiz Yüksek Lisans Bitirme Projesi, Süleyman Demirel Üniversitesi, Isparta.

Yiğitoğlu, R. (2020). Konaklama Isşletmelerinde Turist Azlı̆̆ Durumunda Alternatif Ürün ve Hizmet Geliştirme Stratejilerinin Etkisi: Nevşehir İli Örneği, Yayınlanmamış Yüksek Lisans Tezi, Nevşehir Hacıbektaş Veli Üniversitesi, Nevşehir. 